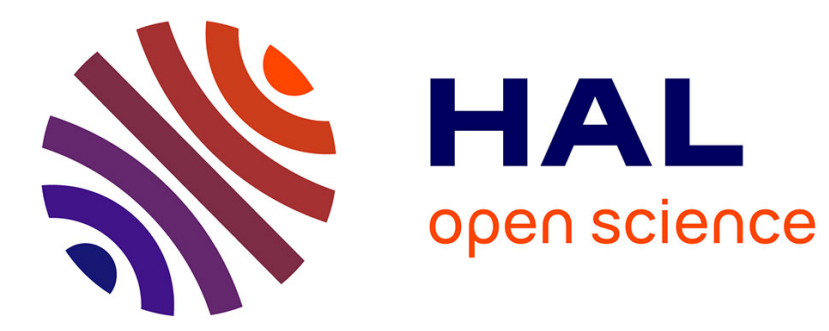

\title{
Legacy effects of temporary grassland in annual crop rotation on soil ecosystem services
}

Kevin Hoeffner, A. Beylich, Abad Chabbi, D. Cluzeau, D. Dascalu, U. Graefe, G. Guzmán, V. Hallaire, J. Hanisch, B.B. Landa, et al.

\section{- To cite this version:}

Kevin Hoeffner, A. Beylich, Abad Chabbi, D. Cluzeau, D. Dascalu, et al.. Legacy effects of temporary grassland in annual crop rotation on soil ecosystem services. Science of the Total Environment, 2021, 780, pp.146140. 10.1016/j.scitotenv.2021.146140 . hal-03225308

\section{HAL Id: hal-03225308 \\ https://hal.science/hal-03225308}

Submitted on 19 May 2021

HAL is a multi-disciplinary open access archive for the deposit and dissemination of scientific research documents, whether they are published or not. The documents may come from teaching and research institutions in France or abroad, or from public or private research centers.
L'archive ouverte pluridisciplinaire HAL, est destinée au dépôt et à la diffusion de documents scientifiques de niveau recherche, publiés ou non, émanant des établissements d'enseignement et de recherche français ou étrangers, des laboratoires publics ou privés. 
Title: Legacy effects of temporary grassland in annual crop rotation on soil ecosystem services

Authors: Kevin Hoeffner ${ }^{1,2}$, Anneke Beylich ${ }^{3}$, Abad Chabbi ${ }^{4,5}$, Daniel Cluzeau ${ }^{2}$, Dumitrita Dascalu $^{6}$, Ulfert Graefe ${ }^{3}$, Gema Guzmán ${ }^{7}$, Vincent Hallaire ${ }^{1}$, Jörg Hanisch ${ }^{8}$, Blanca B. Landa ${ }^{7}$, Deborah Linsler ${ }^{9}$, Safya Menasseri ${ }^{1}$, Maarja Öpik ${ }^{10}$, Martin Potthoff ${ }^{9}$, Mignon Sandor ${ }^{6}$, Stefan Scheu $^{8}$, Rüdiger M. Schmelz ${ }^{3}$, Ilka Engell ${ }^{9}$, Stefan Schrader $^{11}$, Tanel Vahter ${ }^{10}$, Martin Banse $^{12}$, Annegret Nicolai ${ }^{1,2}$, Elke Plaas ${ }^{9,13}$, Tania Runge ${ }^{12}$, Tomas Roslin ${ }^{14}$, Marie-Laure Decau $^{15}$, Siim-Kaarel Sepp ${ }^{10}$, Luis F. Arias-Giraldo ${ }^{7}$, Sylvain Busnot ${ }^{1}$, Marc Roucaute ${ }^{1}$, Guénola Pérès ${ }^{1}$

\section{Addresses:}

1. UMR SAS, INRAE, INSTITUT AGRO AGROCAMPUS OUEST 35000 Rennes, France

2. University of Rennes, CNRS, ECOBIO [(Ecosystèmes, biodiversité, évolution)] - UMR 6553, Rennes, France

3 IFAB Institut für Angewandte Bodenbiologie GmbH, 22337 Hamburg, Germany

4. INRAE, UR P3F, Centre Poitou-Charentes, Lusignan, France

5. UMR ECOSYS, INRAE, AgroParisTech, Université Paris-Saclay, Versailles, France

6. University of Agricultural Sciences and Veterinary Medicine Cluj-Napoca, Cluj-Napoca, Romania

7. Institute for Sustainable Agriculture, CSIC, Cordoba, Spain

8. University of Göttingen, J.F. Blumenbach Institute of Zoology and Anthropology, 37073 Göttingen, Germany

9. University of Göttingen, Centre of Biodiversity and Sustainable Land Use, 37077 Göttingen, Germany

10. Department of Botany, University of Tartu, Lai 40, EE-51005 Tartu, Estonia

11. Johann Heinrich von Thünen-Institute, Institute of Biodiversity, Braunschweig, Germany12. Johann Heinrich von Thünen-Institute, Institute of Market Analysis, Braunschweig, Germany

13. University of Göttingen, Department for Agricultural Economics and Rural Development, Göttingen, Germany

14. Swedish University of Agricultural Sciences, Department of Ecology, Uppsala, Sweden

15. UE FERLUS INRAE, Lusignan, France

\section{Corresponding author:}

Kevin Hoeffner (kevin.hoeffner@gmail.com) 


\section{Introduction}

The sustainability of conventional agricultural practices is a topical concern, particularly in the context of climate change. Conventional agriculture is facing a necessary transition to sustainable agriculture, with a growing population associated with the increase of food demand but also an increasing demands to reduce environmental impacts (Foley et al., 2011; Seufert et al., 2012; Powlson et al., 2014; Gurr et al., 2016). Regarding food demand, conservation agriculture has been advanced as a reliable alternative through the value and stability of the yields (Pittelkow et al., 2015; Knapp and van der Heijden, 2018). Moreover, potential advantages as the promotion of functional soil biodiversity (van Capelle et al., 2012) as well as soil and water preservation (Giller et al., 2015; Hu et al., 2016; Parihar et al., 2016) have been underlined. By definition, conservation agriculture is based on three main principles: minimum mechanical soil disturbance, greater than $30 \%$ permanent soil organic cover and plant species diversification (Giller et al., 2015; Reicosky, 2015; FAO, 2019). Regarding this, one key component of the conservation agriculture strategy is the introduction of temporary grassland into an annual crop rotation, as temporary grassland decrease soil disturbance and enhance soil cover and crop diversification (Lemaire et al., 2015; Martin et al., 2020). The interest of temporary grassland had been underlined by several works: temporary grassland may improve a number of ecosystem services including soil structure maintenance linked to the decrease of erosion risk, water regulation, pathogen regulation and biodiversity conservation (Schwartz et al., 2003; van Eekeren et al., 2008; Christensen et al., 2009; Postma-Blaauw et al., 2010; Conant et al., 2017; Loaiza Puerta et al., 2018; Sirimarco et al., 2018; Martin et al., 2020). If the effect of grassland introduction have been studied, it is also very important to take into account the legacy effect of temporary grassland.

Grassland legacy effects refer to all changes in soil properties achieved through the introduction of grassland, which are passed on to the following crops. The strength of

\section{ACCEPTED MbANUSCRIPT}


grassland legacy effects for successive crops in a rotation system is controversial and likely to depend on i) the duration of the grassland phase (number of years) and management (i.e., seeding, mowing, grazing, and fertilization), ii) the consecutive management practices of the annual crop rotation (i.e., tillage, fertilization, pesticides), and iii) soil properties such as organic matter content and soil structure (van Eekeren et al., 2008; Christensen et al., 2009; Carter and Blair, 2012; Crotty et al., 2016; Panettieri et al., 2017). Such practices, linked to grassland phase or annual crop phase, can either maintain or decrease the legacy effects of grassland (Postma-Blaauw et al., 2010; Crotty et al., 2016; Panettieri et al., 2017; Crème et al., 2018). Compared to an annual crop rotation without grassland, van Eekeren et al. (2008) observed several benefits remaining after three years of crops preceded by three years of grassland: soil organic matter (SOM) and bulk density were 1.7 times higher and 1.1 times lower, respectively, whereas earthworm abundance was 6.2 times higher, and soil structure remained improved, with a higher percentage of crumbs and sub-angular blocky elements. As possible consequence of grassland legacies on soil properties, Christensen et al. (2009) observed that grassland introduction into an annual crop rotation increased yield and nitrogen (N) content in the grain of the following crops.

Although these interesting previous studies gave information about the interest of grassland introduction and/or potential legacy effect of grassland on soil, most of them focus on few soil properties and moreover do not provide links with soil ecosystem services. However, it has been demonstrated that the investigation of a wide range of soil properties can provide a better comprehensive view of soil functioning (Scharenbroch et al., 2005; Teague et al., 2011; Stauffer et al., 2014). Therefore, in this study, we assessed the impact of grassland introduction and duration of grassland in an annual crop rotation, by assessing a broad spectrum of soil parameters (physical, chemical, biological) linked to several soil ecosystem services. In this context, the objectives of the present study were to evaluate (a) the

\section{ACCEPTED MBANUSCRIPT}


effects of grassland introduction in crop rotation, and (b) the legacy effects of the duration of grassland phases during annual crop rotation on different ecosystem services. For that purpose, we selected and assessed five ecosystem services serving as proxies characterizing grassland production systems. Each service was determined by measuring at least one representative parameter: (i) soil structure maintenance (aggregate stability), (ii) water regulation (saturated hydraulic conductivity), (iii) soil biodiversity conservation (microbial biomass and microbial metabolic activity as well as bacterial, fungal, arbuscular mycorrhizal fungal, springtail, enchytraeid and earthworm communities), (iv) pathogen regulation (soil suppressiveness to Verticillium dahliae), and (v) forage production (quantity and quality). Services (i) to (iv) can be assigned to regulating services, and forage production (service v) to provisioning service (Swinton et al., 2007; Dominati et al., 2010). We hypothesized that grassland introduction improves all five ecosystem services compared to an annual crop rotation without grassland and that the longer the duration of grassland in the crop rotation the stronger is the positive grassland legacy.

\section{Materials and methods}

\subsection{Site description and experimental design}

The experimental site is part of the Agro-ecosystems, Biogeochemical Cycles and Biodiversity long-term observatory on environmental research (SOERE ACBB), managed by the French National Institute of Agricultural Research and Environment (INRAE), located in Lusignan, France $\left(46^{\circ} 25^{\prime} 12.91^{\prime \prime} \mathrm{N} ; 0^{\circ} 07^{\prime} 29.35^{\prime \prime} \mathrm{E}\right)$. The climate of the experimental site is oceanic with mean annual precipitation of $797 \mathrm{~mm}$ and mean annual temperature of $11.9{ }^{\circ} \mathrm{C}$, with a monthly minimum of $-3{ }^{\circ} \mathrm{C}$ and a monthly maximum of $27.8^{\circ} \mathrm{C}$ (data from Météo France, 2007-2017). The site is plane with a very slight slope $(0.6 \%)$. The soil is a Plinthic Cambisol (IUSS Working Group, 2015) with a silt loam soil texture (Moni et al., 2010).

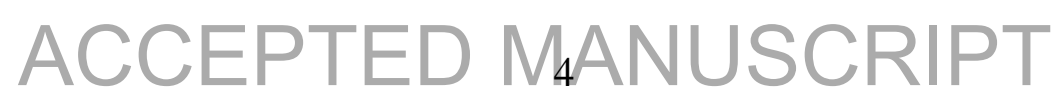


Before the setup of the experimental site in 2005, the area had been under conventional agricultural management for at least 70 years (INRAE archive). In 2017, three treatments were compared (Table 1): (i) a fertilized annual crop rotation with grain maize, winter wheat and winter barley (AC), (ii) a three-year-old grassland preceded by three years of crop, three years of grassland and three years of crop (3G, i.e. 50\% of grassland in the crop rotation), and (iii) a three-year-old grassland preceded by three years of crop and six years of grassland (6G, i.e. $75 \%$ of grassland in the crop rotation). The three treatments were replicated in four random plots of $4000 \mathrm{~m}^{-2}$ each; for more details see Kunrath et al. (2015).

Crops were sown following ploughing (mouldboard ploughing) to a depth of $25 \mathrm{~cm}$ : grain maize was sown in April, harvested in October; wheat was sown in October and harvested in July; barley was sown in November and harvested in July. After barley harvest, soil was bare until sowing of grain maize in April. For maize, firstly, crop residues were crushed and distributed on soil surface at the plot level by mechanical work until the next main crop was planted. Secondly, the remaining crop residues were buried as evenly as possible in the ploughed soil horizon. For wheat and barley, crop residues (straw) were exported. Grasslands were sown in spring, following ploughing to a depth of $25 \mathrm{~cm}$ (with a plough), and harvested (mown) three or four times per year (depending on their productivity). Grasslands were not ploughed neither tilled during the grassland phase (i.e., during three or six years). Grasslands were sown as a mixture of perennial ryegrass (Lolium perenne cv. Milca), tall fescue (Festuca arundinacea cv. Soni) and cocksfoot (Dactylis glomerata cv. Ludac). $\mathrm{N}$ was added by applying mineral fertilizer. On average over the experimental period, annual $\mathrm{N}$ application on grasslands was $167 \mathrm{~kg} \cdot \mathrm{ha}^{-1}$ (divided among applications performed after cutting). For annual crops, $\mathrm{N}$ application rates and timing were adjusted each year using the PC-AZOTE program (Angevin, 1999; Senapati et al., 2016). On average over the experimental period, $\mathrm{N}$ application on annual crops was $106 \mathrm{~kg} \cdot \mathrm{ha}^{-1}$. Fungicides, herbicides

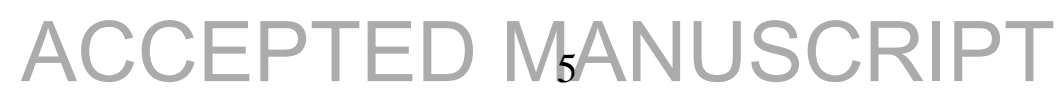


and slug pellets were occasionally applied in the crop phases, while herbicides were only applied at grassland seeding. For wheat and barley a spring herbicide (tribenuron-methyl and thifensulfuron-methyl at $0.0070 \mathrm{~kg} \cdot \mathrm{ha}^{-1}$ ) and a spring fungicide was applied (fluxapyroxad and metconazole at $0.91 \cdot \mathrm{ha}^{-1}$ ). For corn, only a spring herbicide was applied (mesotrionex at $0.5 \mathrm{l} \cdot \mathrm{ha}^{-1}$ and nicosulfuron at $0.3 \mathrm{l} \cdot \mathrm{ha}^{-1}$ ). Occasionally, slug pellets (metaldehyde at $5 \mathrm{~kg} \cdot \mathrm{ha}^{-1}$ ) were applied.

\subsection{Soil sampling, measurement of chemical and physical properties}

Sampling of soil physical and chemical parameters was performed in April 2017 before sowing maize in $\mathrm{AC}$ (bare soil) and during the grassland phases of $3 \mathrm{G}$ and $6 \mathrm{G}$. For soil chemical parameters, one soil sample was collected in each of the four plots per treatment with a split corer (5 cm of diameter) at three depths: 0-10, 10-20 and 20-30 cm (Supplementary Fig. S1). For the soil physical parameter (e.g., aggregate stability), one soil sample of $1 \mathrm{~kg}$ was collected per plot with a spade at two depths: 0-10 and 10-20 cm (Supplementary Fig. S1). Soil samples were then transported to the laboratory in plastic boxes to preserve soil structure.

Prior to soil chemical analyses, samples were sieved (mesh size $2 \mathrm{~mm})$, dried $\left(105^{\circ} \mathrm{C}\right.$ for 24 hours) and ball-milled. Total carbon (C) and total $\mathrm{N}$ were measured by dry combustion (Elementar Vario El, Heraeus, Hanau, Germany). Since no carbonates were detectable using the Scheiber method (Allison, 1960; Blume et al., 2010; Amelung et al., 2018), total C corresponds to soil organic $\mathrm{C}$. The $\mathrm{pH}$ values were determined in distilled water in a soil-towater ratio of 1:2.5. Cation exchange capacity was determined using an inductively coupled plasma-optical emission spectroscopy (ICP-OES, Spectro, Kleve, Germany) following the method of Konig and Fortmann (1996) and total phosphorus (P) was determined by inductively coupled plasma-atomic emission spectroscopy (ICP-AES, Thermo Fischer 
Scientific GmbH, Dreieich, Germany), following the method of the Environmental Protection Agency (1997).

Saturated hydraulic conductivity was measured according to the Beerkan Estimation of Soil Transfer (BEST) protocol (Lassabatère et al., 2006) using a ring with an inner diameter of $30 \mathrm{~cm}$, inserted to a depth of approximately $2 \mathrm{~cm}$ into the soil surface to avoid lateral loss of water. On each plot, one infiltration run was performed (Supplementary Fig. S1). A known volume of water was poured in the cylinder to cover the soil by $1 \mathrm{~cm}$, measuring the elapsed time for its complete infiltration. Then, an identical volume of water was poured into the cylinder and infiltration time was measured again. The procedure was repeated until the difference in infiltration time between consecutive trials became negligible, suggesting a practically steady-state infiltration (Lassabatère et al., 2006). The BEST procedure of Bagarello et al. (2014) was applied to obtain the soil saturated hydraulic conductivity at each infiltration point.

Aggregate stability was measured in the laboratory on one air-dried soil sample per plot (Supplementary Fig. S1) as described by Le Bissonnais (1996; AFNOR X31-515 2005; ISO 10930 2012). In this method, three procedures were applied to aggregates in order to distinguish mechanisms of breakdown: slaking due to fast wetting (FW) occurring during heavy storms on dry soils; microcracking due to slow wetting (SW) occurring during lowintensity rain and mechanical breakdown by shaking aggregates after prewetting (MB) corresponding to aggregate behaviour during continuously wet periods. For the three procedures (FW, SW and MB), aggregate stability was measured on $5 \mathrm{~g}$ of selected macroaggregates (3-5 mm size fraction); thereafter, residual macroaggregates were dried at 40 ${ }^{\circ} \mathrm{C}$ for $48 \mathrm{~h}$ and gently sieved through a six-sieves column $(2.00,1.00,0.50,0.20,0.10$ and $0.05 \mathrm{~mm}$ ) by running 20 identical helicoidal movements. The results were expressed as the resulting fragment size distribution and as the mean weight diameter (MWD), which is the

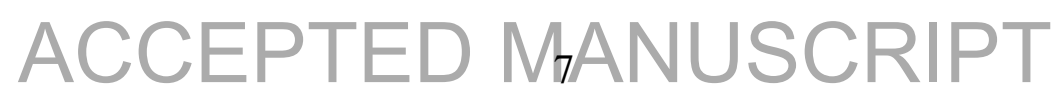


sum of the mass fraction (M) remaining on each sieve after sieving multiplied by the mean aperture (A) of the adjacent sieves. Aggregate stability was expressed by calculating the mean weight diameter $(\mathrm{MWD}, \mathrm{mm})$ of soil macroaggregates as follows: $\mathrm{MWD}=\Sigma(\mathrm{M} \times \mathrm{A}) / 100$ (Le Bissonnais, 1996). Soil water content (WC) was measured by oven drying $10 \mathrm{~g}$ of fresh soil sample at $105{ }^{\circ} \mathrm{C}$ for $24 \mathrm{~h}$. Bulk density was measured with cylinders down to $30 \mathrm{~cm}$ depth and averaged for $0-30 \mathrm{~cm}$ values.

\subsection{Soil sampling for biological analysis}

Sampling of soil biological parameters was performed in April 2017 before tillage and sowing of maize in AC (bare soil) and during the grassland phases of $3 \mathrm{G}$ and $6 \mathrm{G}$. Microbial biomass $\mathrm{C}$ was measured from four soil samples collected per plot, one in each corner of a 20 x $20 \mathrm{~m}$ square established in the plot (Supplementary Fig. S1). In each sample, microbial biomass was measured at three depths: $0-10,10-20$ and 20-30 cm. In the laboratory, soil was sieved through $2 \mathrm{~mm}$ mesh and microbial biomass $\mathrm{C}$ was measured by chloroformfumigation-extraction (Vance et al., 1987). Briefly, for each sample two portions of $10 \mathrm{~g}$ field-moist soil were used, one was fumigated with ethanol-free $\mathrm{CHCl}_{3}$, while the other was not fumigated. Both portions were extracted with $0.5 \mathrm{M} \mathrm{K}_{2} \mathrm{SO}_{4}$ and afterwards the organic $\mathrm{C}$ in each extract was determined (multi N/C 2100S, Analytik Jena, Germany). Microbial biomass $\mathrm{C}$ was calculated as $\mathrm{E}_{\mathrm{C}} / \mathrm{k}_{\mathrm{EC}}$, where $\mathrm{E}_{\mathrm{C}}=$ (organic $\mathrm{C}$ extracted from the fumigated portion) - (organic $\mathrm{C}$ extracted from the non-fumigated portion) and $\mathrm{k}_{\mathrm{EC}}=0.45$ which is the extractable part of microbial biomass C (Wu et al., 1994; Joergensen and Mueller, 1996).

Microbial functional diversity, expressed as ability of microbial community to use different organic substrates as energy source, was measured from four soil samples collected per plot, one in each corner of a 20 x 20 m square (Supplementary Fig. S1). In each sample, microbial functional diversity was measured at two depths: $0-15$ and $15-30 \mathrm{~cm}$. In the 
laboratory, soil was sieved through a $2 \mathrm{~mm}$ mesh and the functional microbial diversity in the soil samples was assessed by measuring $\mathrm{C}$ utilization patterns of fourteen different organic substrates with the MicroResp ${ }^{\mathrm{TM}}$ assay (Campbell et al., 2003). The organic substrates used for the analyses were: D-glucose, D-galactose, D-fructose, L-arabinose, L-trehalose, Larginine, L-lysine, L-alanine, $\gamma$-amino-butyric acid, L-cysteine, citric acid, oxalic acid, $\alpha$ ketoglutaric acid, L-malic acid and water as control. Briefly, soil and substrate mixtures were incubated for $6 \mathrm{~h}$ at $25^{\circ} \mathrm{C}$ and the amount of $\mathrm{CO}_{2}-\mathrm{C}$ released between $\mathrm{T} 0$ (incubation start) and T6 (after $6 \mathrm{~h}$ of incubation) was measured with an indicator gel which changes its color according to the amount of $\mathrm{CO}_{2}$ released. Color change during incubation was measured at $570 \mathrm{~nm}$ using a microplate reader. Substrate utilization pattern given by the amount of $\mathrm{CO}_{2}-\mathrm{C}$ metabolised from each organic substrate was used to compare treatments.

For soil microbial diversity analysis, soil samples were collected at four points per plot, with samples of approximately $10 \mathrm{~g}$ taken with a single-use spoon from a depth of approximately $5 \mathrm{~cm}$ (Supplementary Fig. S1). Soil DNA was extracted from $5 \mathrm{~g}$ dry soil from each sample using the PowerMax ${ }^{\circledR}$ soil DNA isolation kit (MoBio laboratories, Inc; Carlsbad, CA, USA), according to manufacturer instructions with some modifications: combining a $30 \mathrm{~s}$ vortex shaking followed by an incubation step at $60^{\circ} \mathrm{C}$ while shaking at 100 rpm, and drying the samples for $10 \mathrm{~min}$ at room temperature under a fume hood before adding the final elution buffer (Gazol et al., 2016). The same DNA extracts were used for analyzing Arbuscular Mycorrhizal Fungi (AMF), total fungal and bacterial communities.

To characterize bacterial communities, the V4-V5 hypervariable region of 16S rRNA was amplified using primers 515F and 926R (Walters et al., 2016), whereas for the fungal internal transcribed spacer 2 (ITS2) region the primers ITS86(F) / ITS4(R) (Toju et al., 2012) were used. The amplified libraries were paired-end sequenced using an Illumina sequencing platform (V3, PE 2 x300 bp) by the Integrated Microbiome Resource (IMR) at Dalhousie

\section{ACCEPTED MaAUSCRIPT}


University (Canada). For AMF, the primers WANDA (Dumbrell et al., 2011) and AML2 (Lee et al., 2008) were used to amplify $18 \mathrm{~S}$ rRNA gene, sequenced on an Illumina MiSeq platform with 2 x 300 bp paired-end sequencing chemistry at Asper Biogene (Tartu, Estonia).

Amplicon sequence variants (ASVs) libraries for the 16S rRNA gene (bacteria) and ITS (fungi) were checked with FastQC v0.11.8 (Andrews et al., 2014) and aggregated in a single report using MultiQC software v1.8 (Ewels et al., 2016). Short-length, poor-quality and PCR adapter sequences were removed by the Trimmomatic tool v0.39 (Bolger et al., 2014) in order to reduce noise. Filtered reads were processed within QIIME2 (Quantitative Insights Into Microbial Ecology 2) v.2019.10 (Bolyen et al., 2019). An Operational Taxonomic Unit (OTU) table was generated using the DADA2 workflow and de novo clustering with $\mathrm{V}$ SEARCH (Rognes et al., 2016) at $99 \%$ identity to collapse very close sequences and create a non-redundant OTU table. The taxonomic assignment was performed by q2-vsearch QIIME2 plugin to Silva 132 and UNITE databases for bacteria and fungi, respectively at a $97 \%$ similarity.

AMF sequence data were processed following Vasar et al. (2021). Reads were demultiplexed into samples based on double barcodes and allowing for one barcode and one primer mismatch on both reads. Following the removal of barcode and primer sequences, only pairs where both reads had average quality scores of $>30$ were retained. Paired-end reads were combined with FLASh (v1.2.10; Magoč and Salzberg, 2011), using the default thresholds: overlap between 10 - $300 \mathrm{bp}$ and overlap identity at least $75 \%$. Orphan reads were removed. Putative chimeric sequences were identified and removed using VSEARCH (v2.14.1, Rognes et al., 2016) in database mode. Sequences were identified using a BLAST+ search (v2.5.0, Camacho et al., 2009) against AM fungal virtual taxa (VT; phylogenetically defined taxonomic units) in the MaarjAM database (Opik et al., 2010), with $97 \%$ identity and $95 \%$ alignment thresholds.

\section{ACCEPTED MiNUSCRIPT}


Springtails (collembolans) were sampled according to the ISO 23611-2 standard (2006) at the four corners of the $20 \times 20 \mathrm{~m}$ square outlined in each plot using a split corer (5 $\mathrm{cm}$ of diameter) over $5 \mathrm{~cm}$ total depth (Supplementary Fig. S1). Samples were transferred to the laboratory and extracted by high gradient heat extraction (Kempson et al., 1963). Animals were collected in diethylene glycol-water solution (1:1) and stored in $70 \%$ ethanol until identification. If possible, springtails were identified to species following the keys of Hopkin (2007) and Fjellberg (1998, 2007). Springtails were assigned to ecological groups using a trait-based approach. As described by Vandewalle et al. (2010), each species received a score between 0 and 4 for 5 morphological traits according to the level of adaptation to soil environment. The scores were then summed, resulting in a maximum score of 18 for species being well adapted to the soil environment and 0 for species being well adapted to the above ground environment. Subsequently, each species was assigned to one of the following ecological categories: epi-edaphic (score between 0 and 6), hemi-edaphic (score between 7 and 12) and eu-edaphic (score between 13 and 18). The springtail community was characterized by its total abundance, abundance per ecological category, species richness and evenness index.

Enchytraeids were sampled according to the ISO 23611-3 standard (2019) in the four corners of the $20 \times 20 \mathrm{~m}$ square outlined in each plot using a split corer ( $5 \mathrm{~cm}$ of diameter) to a depth of $30 \mathrm{~cm}$ (Supplementary Fig. S1). After extracting the soil samples for $48 \mathrm{~h}$ by a wet funnel technique, the individuals were counted and identified in vivo to species and assigned to one of the following ecological categories: opportunistic species, litter dweller, soil dweller and deepness dweller (Graefe and Schmelz, 1999). The enchytraeid community was then characterized by its total abundance, abundance per ecological category, species richness and evenness index. 
Earthworms were sampled according to the ISO 23611-1 (2018) standard, which combines two sampling methods: a physical (hand-sorting) and chemical (AITC application) extraction. In each plot, earthworms were sampled at the four corners of the 20 x $20 \mathrm{~m}$ square outlined in the plot (Supplementary Fig. S1). At each of the four sampling points, first, earthworms were extracted from a block of soil (area $25 \times 25 \mathrm{~cm}$, depth $20 \mathrm{~cm}$ ) by handsorting. Second, the earthworms from below $20 \mathrm{~cm}$ depth were expelled from the soil by applying 2.51 allyl isothiocyanate (AITC) solution $\left(94 \mathrm{mg} \cdot \mathrm{l}^{-1}\right)$ in the pit left by hand-sorting. The earthworms coming to the surface were collected for $30 \mathrm{~min}$. In the laboratory, earthworms were counted, identified to the species and assigned to one of the following ecological categories: epigeic, epi-anecic (Lumbricus rubellus rubellus, Lumbricus centralis and Lumbricus terrestris), strict-anecic (Aporrectodea longa longa and Aporrectodea giardi) and endogeic (Bouché, 1977; Hoeffner et al., 2019). The earthworm community was characterized by its total abundance, abundance per ecological category, species richness and evenness index.

For soil suppressiveness, four soil samples $(20 \times 20 \mathrm{~cm})$ were collected per plot at a depth of 0-20 cm (Supplementary Fig. S1). In the laboratory, soil samples from the same plot were joined to obtain a composite sample for each plot, air dried, sieved though a 4-mm mesh, and stored at $5{ }^{\circ} \mathrm{C}$ until use. A soil suppressiveness experiment with the soilborne pathogen Verticillium dahliae (fungal pathogen) was conducted using the model pathosystem $V$. dahliae-defoliating pathotype/watermelon cv. 'Sugar baby'. The pathogenicity test was performed under growth chamber conditions highly conducive for disease development as described in Jiménez-Fernández et al. (2015). To determine the capability of each treatment to reduce disease development, seeds of watermelon were sown in soil inoculated with the pathogen; non-inoculated soil was also used to determine the plant growth in the absence of the pathogen (4 plants/treatment). Each treatment was repeated three times (12 
pots/treatment). Disease development was assessed weekly in each individual plant by the incidence $(0=$ plant with no symptoms, $1=$ plant showing symptoms $)$ and severity of the disease assessed by visual observation of foliar symptoms (wilting, yellowing and necrosis) in each individual plant using a 0 to 4 rating scale according to the percentage of foliage with disease symptoms $(0=0 \%, 1=1$ to $25 \%, 2=26$ to $50 \%, 3=51$ to $75 \%$, and $4=76 \%$ dead plant). The final number of infected plants, as determined by vascular isolation of the pathogen from main stem, for each treatment was recorded at the end of the experiment (Jiménez-Fernández et al., 2015). Additionally, plant physiological variables including plant height and fresh weight were measured for all treatment combinations at the end of the experiment (3 months).

\subsection{Grassland forage production and quality}

Forage production was measured the year before sampling of soil physical, chemical and biological parameters. In 2016, the grass was cut twice (May and June). Aboveground biomass was estimated by cutting an area of $1.5 \times 5.0 \mathrm{~m}$ with an experimental harvester (Haldrup, Germany). The grass harvested was dried in an oven at $70{ }^{\circ} \mathrm{C}$ and weighed to determine dry matter content and then ground for chemical analysis. Total $\mathrm{C}$ and $\mathrm{N}$ concentrations were determined by the Dumas method using an elemental analyser (Carlo Erba EA 1108, Milan, Italy).

\subsection{Statistical analyses}

Statistical analyses were performed with the R software 3.2.3 (R. Core Team, 2019). We tested residuals for normality (Shapiro test) and homogeneity of variance (Bartlett test); when data deviated from ANOVA assumptions, we used appropriate transformations, 
specifically log and square-root transformations. Significance was evaluated in all cases at $P$ $<0.05$

Soil physico-chemical parameters $(\mathrm{C}, \mathrm{N}$ and $\mathrm{P}$ content, cation-exchange capacity, $\mathrm{pH}$, soil moisture, and bulk density) were analyzed by two-way ANOVAs followed by Tukey HSD tests for post hoc pairwise comparisons to inspect for effects of treatments (AC, 3G and 6G) and blocks for each depth $(0-10,10-20$ and 20-30 cm) on each physico-chemical soil parameter. Saturated hydraulic conductivity also was analyzed by two-way ANOVA followed by Tukey HSD tests for post hoc pairwise comparisons to inspect for effects of treatments (AC, 3G and 6G) and blocks on saturated hydraulic conductivity. Aggregate stability (SW, FW and MB) was analyzed by two-way ANOVAs followed by Tukey HSD tests for post hoc pairwise comparisons to inspect for effects of treatments (AC, 3G and 6G) and blocks for each depth (0-10 and 10-20) and each aggregate stability measure. Regarding soil biological conservation, first OTUs and species richness were determined for each sampling. We further calculated Pielou's evenness $\left(\mathrm{J}^{\prime}\right)$ as follows: $J^{\prime}=H^{\prime} / \ln N$, where $\mathrm{N}$ represents the total number of OTUs or species and H' represents the Shannon-Wiener diversity index. Second, we used individual linear mixed-effects models ("nlme" package), followed by Tukey HSD tests for post hoc pairwise comparisons, to inspect for effects of the three treatments (AC, 3G and 6G) and blocks on the abundance and diversity of each organism group (bacteria, fungi, AMF, springtails, enchytraeids and earthworms). The non-independence of samples within plots was addressed by specifying a nested design in the random effect of the model. Third, in order to compare the structure of bacterial, fungal, AMF, enchytraeid, springtail, and earthworm communities between the treatments (AC, 3G and $6 \mathrm{G})$ a data matrix of pairwise compositional distances among samples was calculated using Bray-Curtis dissimilarity. NonMetric Multi-Dimensional Scaling (NMDS, "vegan" package) was used to identify the best low-dimensional representation of the distance matrix. The null hypothesis of no difference

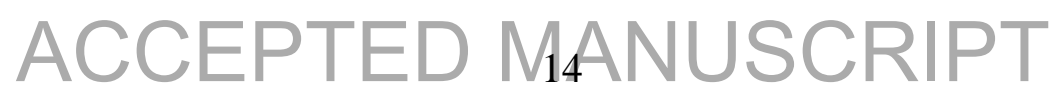


among crop rotation treatments in bacterial, fungal, AMF, enchytraeid, springtail, and earthworm communities was inspected by permutational multivariate analysis of variance (PERMANOVA, "vegan" package) run on the Bray-Curtis distance with 1000 permutations per analysis. Soil suppressiveness was analyzed by individual one-way ANOVAs followed by Tukey HSD tests for post hoc pairwise comparisons to inspect for effects of treatments (AC, $3 \mathrm{G}$ and $6 \mathrm{G}$ ) on final severity, infected plants, plant height- $V$. dahliae, plant weight- $V$. dahliae, plant height-control and plant weight-control. Forage production and quality were analyzed by individual two-way ANOVAs followed by Tukey HSD tests for post hoc pairwise comparisons to inspect for effects of treatments (AC, 3G and 6G) and blocks on forage production and quality ( $\mathrm{C}$ and $\mathrm{N}$ content).

\section{Results}

In 2017, $\mathrm{C}(0-10$ and 10-20 $\mathrm{cm}$ depth) and $\mathrm{N}(0-10 \mathrm{~cm}$ depth) contents were significantly higher in $6 \mathrm{G}$ than in the AC treatment; however, they did not differ between $3 \mathrm{G}$ and $6 \mathrm{G}$ treatments (Table 2). Conversely, $\mathrm{pH}$ was significantly higher in $\mathrm{AC}$ than in $6 \mathrm{G}$ treatment, while again there was no difference between $3 \mathrm{G}$ and $6 \mathrm{G}$ treatments (Table 2). $\mathrm{P}$ content, cation-exchange capacity and bulk density were not different between the treatments regardless of soil depth (Table 2).

\subsection{Effects of temporary grassland introduction}

In comparison to annual crop rotation, the introduction of either 3 or 6 years of grassland in the rotation promoted soil structure maintenance and some biodiversity conservation indicators, but decreased soil suppressiveness (Tables 3, 4, 5 and 6, Fig. 1). Compared to the annual crop rotation, both grassland treatments significantly increased aggregate stability with slow wetting (depth $0-10 \mathrm{~cm}$ ) by at least $38 \%$ and tended to increase

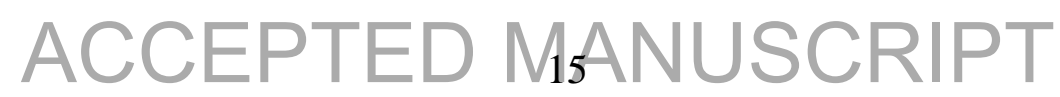


aggregate stability with fast wetting by at least $22 \%(P=0.064$, depth $0-10 \mathrm{~cm})$; no effect was observed at deeper strata $(10-20 \mathrm{~cm}$; Table 3$)$. Both grassland treatments significantly increased microbial biomass (depth $10-20 \mathrm{~cm}$ ) by at least $29 \%$ and eu-edaphic springtail abundance by at least $79 \%$, permitted the development of litter dweller enchytraeids, which were absent in the annual crop and tended to increase AMF abundance by $58 \%$ (significantly for the grassland with a medium percentage in the crop rotation; Tables 4 and 5). Moreover, grassland treatments increased earthworm total abundance (almost solely due to increased numbers of anecic earthworms) and richness by at least $34 \%$ and $19 \%$, respectively (Table $5)$.

Conversely, the introduction of grassland into an annual crop rotation decreased the abundance of opportunistic enchytraeid species, especially in the grassland with a medium percentage $(50 \%)$ of grassland in the crop rotation, where abundance significantly decreased by $91 \%$ (Table 5). In addition, both grassland treatments significantly reduced soil suppressiveness to an introduced soilborne pathogen (Table 6). At the end of the experiment, the final disease severity level increased by at least $90 \%$ and the percentage of infected plants increased by at least $80 \%$ for both grassland treatments. Interestingly, although there were no effects of grassland introduction on growth of watermelon plants when grown on $V$. dahliae infested soil, grassland introduction significantly increased the growth of the plants by at least $21 \%$ and $28 \%$ in length and weight, respectively, when grown on a non-infested soil (Table $6)$.

Beyond these effects, grassland introduction did not detectably modify (i) bacterial, fungal and enchytraeid species richness (Tables 4 and 5), (ii) bacterial, fungal, springtail, enchytraeid and earthworm evenness (Tables 4 and 5), and (iii) microbial metabolic activity (Supplementary Table S1). Furthermore, grassland introduction significantly changed the community composition of bacteria, fungi, AMF (composition of OTUs) and earthworms 
(composition of species; Fig. 1a, b, c and f), while it did not affect springtail and enchytraeid communities (composition of species; Fig. 1d and e). In addition, grassland introduction did not impact water regulation as saturated hydraulic conductivity was not significantly different between the annual crop and the two grasslands, with values of $1.31 \pm 0.23( \pm \mathrm{SE})$ and $1.40 \pm$ $0.16( \pm \mathrm{SE}) \mathrm{mm} \mathrm{s}^{-1}$, respectively (Table 3$)$.

\subsection{Grassland legacy effects}

A comparison of the two grassland treatments, which allowed the assessment of legacy effects (50\% grassland vs $75 \%$ grassland of grassland in the crop rotation), showed that legacy effects significantly impacted soil structure maintenance and biodiversity conservation for some indicators (Tables 3, 4 and 5, Fig. 1). Regarding soil structure maintenance, higher grassland percentage $(75 \%)$ in the crop rotation significantly increased aggregate stability with respect to mechanical breakdown (depth $10-20 \mathrm{~cm}$ ) by $16 \%$, while

with slow and fast wetting no difference was observed (Table 3). Regarding biodiversity conservation, higher grassland percentage $(75 \%)$ in the crop rotation significantly increased AMF evenness by $24 \%$, microbial biomass (depth $20-30 \mathrm{~cm}$ ) by $18 \%$, epi-edaphic springtail abundance by $71 \%$, total springtail richness by $32 \%$ and litter dweller enchytraeid abundance by $84 \%$ compared to the lower grassland percentage (50\%) in the crop rotation (Tables 4 and 5). In addition, AMF communities (composition of OTUs) were significantly different between the two grassland treatments (Fig. 1c).

Despite these positive impacts, increasing grassland percentage in the crop rotation did not impact global indicators of biodiversity conservation (i.e., total abundance, richness and biomass; except microbial biomass 20-30 cm depth) (Tables 4 and 5). Furthermore, it did not impact finer indicators of soil biodiversity such as the evenness of bacteria, fungi, springtails, enchytraeids and earthworms (Table 5) as well as the community composition (OTUs or

\section{ACCEPTED MANUSCRIPT}


species) of bacteria, fungi, springtails, enchytraeids and earthworms (Fig. 1a, b, d, e and f). Between the two grassland treatments there was no difference in soil suppressiveness, with final disease severity ranging from 2.4 to 2.7 and the final percentage of infected plants ranging from $90 \%$ to $100 \%$. Similarly, growth of the test plant used for the soil suppressiveness was not affected by the grassland treatments (Table 6). In addition, the increase in grassland percentage in the crop rotation did not modify water regulation and forage production and quality. Within each grassland treatment saturated hydraulic conductivity ranged from 0.8 to $2.2 \mathrm{~mm} \mathrm{~s}^{-1}$ (Table 3), and mean aboveground forage production was $3.3 \pm 0.4( \pm \mathrm{SE}) \mathrm{t} \mathrm{ha}^{-1}$, mean forage $\mathrm{C}$ content was $440.7 \pm 1.0( \pm \mathrm{SE}) \mathrm{mg} \cdot \mathrm{g}^{-1}$ and mean forage $\mathrm{N}$ content was $20.0 \pm 0.5( \pm \mathrm{SE}) \mathrm{mg} \cdot \mathrm{g}^{-1}$ (Table 7).

The extent of the grassland legacy effect on biodiversity conservation was partly combined with the effect of grassland introduction in the annual crop rotation. On the one hand, compared to the annual crop rotation, grassland introduction with a medium percentage $(50 \%)$ of grassland in the annual crop rotation significantly decreased opportunistic enchytraeid species abundance by $91 \%$ (Table 5$)$ and tended to decrease fungal richness $(P=$ 0.074, Table 4). Additionally, springtail and enchytraeid communities were significantly different in grassland with a medium percentage $(50 \%)$ of grassland in the crop rotation compared to the annual crop rotation (Fig. 1d and e). On the other hand, compared to the annual crop rotation, including grassland with a higher grassland percentage $(75 \%)$ in the crop rotation significantly increased microbial biomass (depth $0-10 \mathrm{~cm}$ ) by $30 \%$ and AMF richness by $29 \%$ (Table 4).

\section{Discussion}

4.1. Grassland introduction increased biodiversity conservation and soil structure maintenance 
We hypothesized that grassland introduction in an annual crop rotation would boost ecosystem services in general. Contrary to this generalization, we observed variable effects depending on the assessed ecosystem service. Regarding biodiversity conservation, regardless of the duration of the grassland phase in the rotation, grassland introduction significantly increased microbial biomass (10-20 cm depth), earthworm richness and abundance, especially anecic earthworms. Moreover, grassland introduction permitted the presence of litter dwelling enchytraeids, propped up abundances of eu-edaphic springtails and tended to increase AMF abundance. For microbial biomass and AMF abundance as well as for anecic earthworm abundance and biomass, these findings are consistent with those of previous studies (PostmaBlaauw et al., 2010; Cluzeau et al., 2012; Linsler et al., 2015; Banerjee et al., 2019) and could be related to the cessation of soil tillage which is known to detrimentally affect anecic earthworms (Briones and Schmidt, 2017) and AMF abundance (Vályi et al., 2015). Moreover, the supply of food resources (i.e., plant materials) and the low level or absence of pesticide application may also have beneficially affected microbial biomass, AMF abundance and earthworms (Wardle, 1992; Pelosi et al., 2013; Banerjee et al., 2019). Regarding litter dwelling enchytraeids, our findings are consistent with their diet consisting mainly of decomposed plant materials (Graefe and Schmelz, 1999; Gajda et al., 2017), which can accumulate at the soil surface with grassland introduction. Grassland could also provide a physical good habitat for litter dwellers by creating a densely rooted, crumbly top-soil layer with high organic matter content and low bulk density. Surprisingly, among springtail ecological groups, only eu-edaphic springtails benefitted from grassland introduction. Considering that they live deeper in the soil profile, this group should be least sensitive to changes in plant coverage. However, of the springtail ecological groups eu-edaphic species may benefit most from root resources (Scheunemann et al., 2015) and have been shown to be able to switch to feeding on roots rather than soil organic matter resources when roots are in

\section{ACCEPTED MigANUSCRIPT}


ample supply (Endlweber et al., 2009). In fact, van Eekeren et al., (2008) observed that compared to an annual crop rotation, the number of roots in autumn from 0 to $10 \mathrm{~cm}$ in a 3year temporary grassland increased by $83 \%$. Such dense roots and root resources presumably provided additional food supply, particularly to eu-edaphic springtails. Moreover, their low abundance under annual crops could be explained by their restricted dispersal capacity (Chauvat et al., 2014), which could make them more vulnerable to predation and environmental conditions when they are forced to be on the soil surface during soil ploughing under annual crops. Conversely, both grassland treatments tended to decrease opportunistic enchytraeid species with a medium percentage of grassland having the lowest values of all treatments. Our findings hence contrast those of van Eekeren et al. (2008) and Postma-Blaauw et al. (2010) who reported that the introduction of grasslands into an annual crop rotation had either no effect or a positive effect on soil biodiversity, including enchytraeid. Opportunistic enchytraeid species are pioneer species with a high reproduction rate, able to thrive in disturbed environments with unbalanced food resources (Jänsch et al., 2005); in more stable and structured environments such as grasslands they are reduced potentially due to competition with other more specialized or more demanding species (Graefe and Schmelz, 1999). Overall, our study documented that the introduction of grassland, even if it is a species poor grassland (with three plant species sown) and functionally homogeneous grassland, into an annual crop rotation, positively impacts biodiversity conservation on global parameters (total abundance, biomass and diversity), and also on finer parameters such as functional categories and species or OTU composition.

Despite changes in microbial biomass (10-20 cm depth) and bacterial and fungal OTU composition between grasslands and the annual crop rotation, microbial metabolic activity was not affected by the introduction of grassland. In the present study, increasing the biomass and modifying the diversity of soil microorganisms through the introduction of grassland into

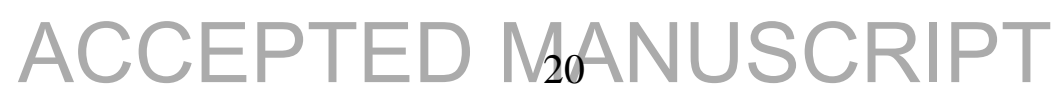


the annual crop rotation did not result in changes in organic substrate utilization pattern. Potentially, this was due to functional redundancy between and/or within bacterial and fungal OTUs (Rousk et al., 2009; Souza et al., 2015; Mendes et al., 2015; Banerjee et al., 2016). More than that, Ros et al., (2006) suggested that CLPP should be combined with other methods to analyze microbial community structure and functional diversity in order to assess the impact of land management on soil microbial metabolic activity.

Regarding pathogen regulation, both types of grassland introduction $(50 \%$ or $75 \%$ ) decreased soil suppressiveness to $V$. dahliae. The effects of agricultural management practices (especially soil rotations) on soil suppressiveness to soilborne plant pathogens and their interactions with soil biotic and abiotic factors are not fully understood (Weller et al., 2002). Indeed, soils with similar physicochemical characteristics may correlate in different ways with soil suppressiveness depending on the pathogen, the crop plant assessed, and the previous history of host plants cropped (Janvier et al., 2007; Schlatter et al., 2017). In our study, the annual crop rotation showed higher soil suppressiveness to $V$. dahliae, as indicated by the lower disease severity level and lower number of infected plants. Potentially, this was due to differences in fungicide application in the annual crop treatment, which may have altered overall fungal richness and community structure, as was observed in our study, including other fungal pathogens as well as potential fungal competitors/antagonists of $V$. dahliae (Bending et al., 2007; Mommer et al., 2018). V. dahliae cannot be reached by many fungicides during its parasitic phase inside the plants; however, a residual fungicidal effect against $V$. dahliae conidia inoculated on the soil cannot be ruled out, which may have resulted in a lower inoculum potential for the $\mathrm{AC}$ treatment compared to the grassland treatments where no fungicide was applied (Rampersad, 2010). In addition, the annual crop soils exhibited lower $\mathrm{C}$ and $\mathrm{N}$ concentrations, and higher $\mathrm{pH}$, parameters that may have influenced pathogen germination and activity in the soil immediately after inoculation and before the

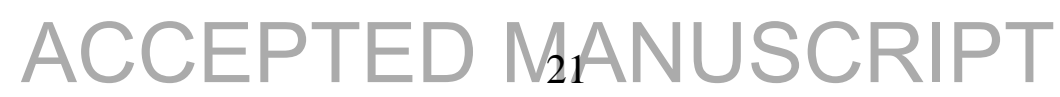


plant vascular infection occurred (Jones and Woltz, 1972). Korthals et al. (2014) highlighted that the influence of soil biota on disease suppressiveness to $V$. dahliae may exceed that of soil chemical variables, suggesting that the different bacterial and fungal communities (including $\mathrm{AMF}$ ) in the annual crop and grassland treatments accounted for the suppressiveness effect (Postma et al., 2008). However, further studies are needed to determine whether specific microorganisms are responsible for the disease suppressiveness effect observed.

Regarding water regulation, values of the saturated hydraulic conductivity in our study were similar to those observed in previous studies (Lamandé et al., 2003; Schwartz et al., 2003; Gonzalez-Sosa et al., 2010). Neither type of grassland introduction modified saturated hydraulic conductivity, contrasting previous studies showing pronounced positive effects of grassland introduction (Schwartz et al., 2003; Bodhinayake and Si, 2004; Jarvis et al., 2013). Moreover, the lack of effects was unexpected as introduction of grassland was associated with higher abundances of a number of organisms including earthworms, which are recognized to increase hydraulic conductivity due to their burrows functioning as preferential water flow paths (Weiler and Naef, 2003; Blouin et al., 2013; Fischer et al., 2014). However, higher earthworm abundance does not necessarily indicate a higher number of burrows (Pérès et al., 2010) and a resulting increase in saturated hydraulic conductivity. Identical rates of saturated hydraulic conductivity in the crop rotation and both grasslands could be explained by a balance between the effect of tillage in the annual crop rotation, which aerates the soil and creates porosity, and biological action. Indeed, previous studies reported that plough-till systems may increase hydraulic conductivity compared to no-till systems as due to increases in inter-aggregate flow-active porosity and pore continuity (Lipiec et al., 2006; BlancoCanqui et al., 2017). 
Regarding soil structure maintenance, both grassland introductions into an annual crop rotation increased aggregate stability with slow wetting $(0-10 \mathrm{~cm}$ depth). Aggregate stability with slow wetting can be enhanced by the action of polysaccharides secreted by bacteria, which attenuate micro cracking of aggregates (Chenu, 1989; Le Bissonnais, 1996; Abiven et al., 2007). In our study, the significant higher values of aggregate stability with slow wetting $(0-10 \mathrm{~cm}$ depth $)$ in both grasslands might be related to the slight increase of microbial biomass in grassland treatments compared to that of the annual crop treatment $(0-10 \mathrm{~cm}$ depth; Pérès et al., 2013; Linsler et al., 2015) certainly due to the presence of permanent grass roots (Pérès et al., 2013). Compared to the annual crop, both grassland introductions tended to increase aggregate stability with fast wetting (especially $0-10 \mathrm{~cm}$ depth), which is commonly linked to the action of fungi and root biomass to enmesh a large number of particles able to resist aggregate disruption (Chenu, 1989; Le Bissonnais, 1996; Abiven et al., 2007; Pérès et al., 2013). As we observed an increase in AMF abundance in both grassland treatments (significant in the grassland with a medium percentage of grassland in the annual crop rotation) we hypothesized that, apart from the effect of grass roots, the highest levels of AMF hyphae measured in both grassland treatments could improve aggregate stability with fast wetting. However, it is possible that the increase of AMF hyphae measured was not enough to increase significantly aggregate stability with fast wetting. Again, overall, grassland introduction, even if it is a species poor grassland (with three plant species sown) and functionally homogeneous grassland, into an annual crop rotation, improved soil stability which limit soil compaction and/or erosion.

\subsection{Grassland legacies last for a long time}

We hypothesized that the longer the duration of grassland in the crop rotation, the greater is the positive grassland legacy. Contrasting with this expectation, we observed a long-

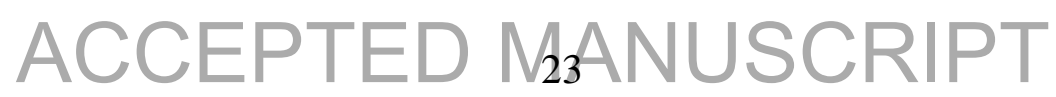


lasting grassland legacy effect on biodiversity conservation for some biological parameters and on soil structure maintenance, but not on pathogen regulation (soil suppressiveness), water regulation (saturated hydraulic conductivity) and forage production (quantity and quality). In the literature, it is demonstrated that the legacy effect of grasslands on biodiversity conservation for the successive crops varies among studies. For example, Postma-Blaauw et al. (2010) noticed a short term legacy effect from 1 to 3 years for a broad range of soil biota (abundance of earthworms, enchytraeids, microarthropods, nematodes and protozoa as well as fungal and bacterial biomass), while Crème et al. (2018) found that microbial biomass still benefited from the previous grassland after three years of crops. In our study, the legacy effect of increased grassland permanence in the crop rotation had a positive effect on microbial biomass (especially in 20-30 cm depth), AMF richness and evenness, as well as epi-edaphic springtail abundance, total springtail richness and enchytraeid litter dweller abundance. Presumably, these effects were due to increased plant residues and diversity as well as by lower levels of soil disturbance in the treatments with increased grassland permanence (Wolters, 1991; Bardgett and Cook, 1998; Graefe and Schmelz, 1999; Oehl et al., 2003; Vályi et al., 2015). Notably, a grassland legacy effect was also observed for AMF OTU composition, which was significantly different between the two grassland treatments. This could be linked to the speed of development of crop specialist species vs grassland species: as soon as grassland is introduced, the AMF OTUs specialized on the crop decreased; conversely, the return of the OTUs specialized on grassland presumably takes much longer (Vályi et al., 2015; French et al., 2017).

Interestingly, bacterial, fungal and earthworm communities were not affected by the percentage of grassland duration. For earthworms, these findings could be explained by their high colonization and foraging capacity compared to the other organisms studied (Eijsackers, 2011), allowing them to return to a stable state, close to that in permanent grassland, after at 
least three years of grassland (van Eekeren et al., 2008; Postma-Blaauw et al., 2010). For bacteria and fungi, changes in their communities have been observed depending on the composition of the organic matter to be degraded (Hossain et al., 2010; Pascault et al., 2010; Urbanová et al., 2015; Hoeffner et al., 2018). However, in our study, the similarity of plant materials deposited on the soil and the legacy of the SOM kept from year to year may have led to a relatively similar molecular composition of SOM (Panettieri et al., 2017; Crème et al., 2018). Panettieri et al. (2017) observed at the same study site that with respect to SOM, the grassland footprint was still dominant after three years of continuously cropping the grassland. Given this, the similarity of bacterial and fungal communities between these two grasslands could be explained by the similarity in molecular composition of the SOM. Overall, our findings emphasize that the value of extending grassland duration in the crop rotation for biodiversity conservation does not apply to all organisms or to all indicators within a considered group of organisms.

Regarding soil structure maintenance, increasing the percentage of grassland in the crop rotation increased aggregate stability under mechanical breakdown (10-20 cm depth), but did not affect aggregate stability under slow and fast wetting tests $(0-10$ and 10-20 cm depth). Our findings hence contrast those of Abiven et al. (2007), who reported in controlled conditions that aggregate stability under mechanical breakdown test was correlated with fast wetting, and both were linked to the mechanical actions of fungi or roots (Chenu, 1989; Le Bissonnais, 1996; Abiven et al., 2007; Pérès et al., 2013). In line with our results, Abiven et al. (2007) observed that aggregate stability with mechanical breakdown was linked to fungal hyphal length, which in our study could be associated with the increase in AMF abundance in grassland treatments. In addition, aggregate stability with mechanical breakdown could be related to enchytraeids, especially soil dwellers and litter dwellers, and to springtails which also increased with the percentage of grassland in the crop rotation. Indeed, enchytraeids and

\section{ACCEPTED MaANUSCRIPT}


springtails are also known to contribute to the stability of soil aggregates (Marinissen and Didden, 1997; Maaß et al., 2015; Lehmann et al., 2017). For example, under controlled conditions, springtails and AMF have been observed to increase the amount of water-stable aggregates, and springtail effects were similar to those of AMF (Siddiky et al., 2012). Interestingly, we observed no legacy effect on aggregate stability with slow and fast wetting (0-10 and 10-20 cm depth), which might reflect that whatever the duration of grassland in the rotation, plant roots stabilize soil particles directly by releasing material or enmesh soil particles promoting soil aggregation (Burri et al., 2009; Fattet et al., 2011). Overall, the benefit of increasing the duration of grassland in the crop rotation is remarkable but limited to certain aggregative processes and to deep depth.

Surprisingly, increasing the percentage of grassland in the crop rotation did not modify forage production (quantity and quality), while abundance/biomass of a large number of organisms known to affect plant growth increased with the percentage of grassland. In particular micro-organisms, enchytraeids and springtails (Filser, 2002; Gange, 2000; Partsch et al., 2006) tended to be or were significantly more abundant in the treatment with a high percentage of grassland in the crop rotation. In the present study, both grasslands exported between 3.15 and $3.53 \mathrm{t} \mathrm{DM} \mathrm{ha}^{-1} \mathrm{yr}^{-1}$, which is much lower than the $7.7 \mathrm{t} \mathrm{DM} \mathrm{ha}^{-1} \mathrm{yr}^{-1}$ predicted in the same French district (Graux et al., 2020). However, the INRAE experimental sites receive only $\mathrm{N}$ fertilization, and deficiency in other macronutrients (e.g. P, $\mathrm{K}, \mathrm{S}, \mathrm{Ca}, \mathrm{Mg}$ ) may limit plant growth (Maathuis, 2009) and thus explain the lack of effect of the grassland duration on forage production; furthermore, climate properties may also play a role (Fay et al., 2003).

Overall, our findings suggest that grassland introduction promotes a wide range of services and may last for almost a decade. Thus, to evaluate the effect of agricultural practices on soil properties it is necessary to take into account legacy effects and consider long time

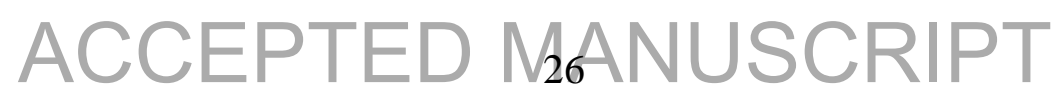


steps. From a policy point of view, temporary grassland in Europe is cultivated and reseeded at least every five years due to the cross-compliance obligations of the Common Agricultural Policy (CAP). From this perspective, these obligations do not sufficiently contribute to the objective of halting and reversing the loss of biodiversity, nor do they lead to sufficient improvement of ecosystem services such as soil structure maintenance. Therefore, we recommend that the CAP should recognize the need for greater flexibility in farmers' decision-making. Instead of imposing the permanent preservation of formerly temporary grasslands, policy should rather leave room for or even incite increasing grasslands in rotations through environmental measures.

\section{Conclusions}

Using a multi-ecosystem services approach, our study argues for extending the duration of grassland within annual crop rotation systems. The introduction of grassland, even a species poor grassland (with three plant species sown) and functionally homogeneous grassland, into an annual crop rotation, as well as the legacy effects of long-time grassland in the rotation, improve soil structure maintenance and substantially enhance habitat suitable for soil biodiversity conservation. While the service of soil suppressiveness decreased, water regulation was not affected by grasslands in the crop rotation. Although responses to grasslands in the rotation are complex and vary among ecosystem services, our results highlight that ecosystem services provision is regulated over long time periods. The positive grassland legacy effects are more pronounced and longer lasting with the introduction of six years of grassland in the rotation. Therefore, including six years of grassland into the crop rotation compared to three years seems to be advantageous for benefitting from increased provisioning of ecosystem services, and maintaining such long rotations may increase the provisioning of a wider range of ecosystem services.

\section{ACCEPTED M2ANUSCRIPT}




\section{Acknowledgements}

This work was supported by the EU SoilMan project (grant number 01LC1620) funded through the 2015-2016 BiodivERsA COFUND call for research proposals, with national funders the Federal Ministry of Education and Research (BMBF), the French National Research Agency (ANR), the Swedish Research Council for Environment, Agricultural Sciences and Spatial Planning (FORMAS), the Spanish Ministry of Economy and Competitiveness (MINECO), the Executive Agency for Higher Education, Research, Development and Innovation Funding (UEFISCDI), the European Regional Development Fund (Centre of Excellence EcolChange). We would like to thank the National Research Infrastructure "Agro-écosystèmes, Cycles Biogéochimique et Biodiversité" (ACBB) http://www.soere-acbb for providing access to an excellent field experiment and the "the AnaEE France (ANR-11-INBS-0001)", "AllEnvi" and "CNRS-INSU” which support it. We thank Météo France for meteorological data. We are deeply indebted to Xavier Charrier, François Gastal, Sarah Guillocheau, Clément Bertran, Albin Fertil, Muriel Guernion, Alan Schneider, Daniel Cylly, Denis Piron, André Bastin, Martial Cocquio and Nicolas Tellier for their help and support during field sampling. We also thank Yannick Besnard, Laurence Carteaux and the Department for Soil Science of Temperate Ecosystems (University of Goettingen) and the Institute for Soil Science (University of Goettingen) for their help during laboratory analysis. 


\section{References}

Abiven, S., Menasseri, S., Angers, D.A., Leterme, P., 2007. Dynamics of aggregate stability and biological binding agents during decomposition of organic materials. Eur. J. Soil Sci. 58, 239-247.

AFNOR, 2005. Soil quality - Measurement of the stability of soil aggregates for assessment of liability to surface sealing and hydric erosion. NF X31-515.

Allison, L.E., 1960. Wet-combustion apparatus and procedure for organic and inorganic carbon in soil. Soil Sci. Soc. Am. J. 24, 36-40.

Amelung, W., Blume, H.-P., Fleige, H., Horn, R., Kandeler, E., Kögel-Knabner, I., Kretzschmar, R., Stahr, K., Wilke, B.-M., 2018. Scheffer/Schachtschabel Lehrbuch der Bodenkunde, 17th ed. Springer Spektrum, Heidelberg.

Andrews, S.F., Krueger, F., Seconds-Pichon, A., Biggins, F., Wingett, S.F., 2014. FastQC: A quality control tool for high throughput sequence data. Babraham Bioinformatics, Babraham Institute, Cambridge, United Kingdom.

Angevin, F., 1999. Raisonnement de la fertilisation azotée. Le logiciel PCazote en PoitouCharentes. Oléoscope 54, 32-34.

Bagarello, V., Di Prima, S., Giordano, G., Iovino, M., 2014. A test of the Beerkan Estimation of Soil Transfer parameters (BEST) procedure. Geoderma 221-222, 20-27.

Banerjee, S., Kirkby, C.A., Schmutter, D., Bissett, A., Kirkegaard, J.A., Richardson, A.E., 2016. Network analysis reveals functional redundancy and keystone taxa amongst bacterial and fungal communities during organic matter decomposition in an arable soil. Soil Biol. Biochem. 97, 188-198.

Banerjee, S., Walder, F., Büchi, L., Meyer, M., Held, A.Y., Gattinger, A., Keller, T., Charles, R., van der Heijden, M.G.A., 2019. Agricultural intensification reduces microbial network complexity and the abundance of keystone taxa in roots. ISME J. 13, 17221736.

Bardgett, R.D., Cook, R., 1998. Functional aspects of soil animal diversity in agricultural grasslands. Appl. Soil Ecol. 10, 263-276.

Bending, G.D., Rodríguez-Cruz, M.S., Lincoln, S.D., 2007. Fungicide impacts on microbial communities in soils with contrasting management histories. Chemosphere 69, 82-88.

Blanco-Canqui, H., Wienhold, B.J., Jin, V.L., Schmer, M.R., Kibet, L.C., 2017. Long-term tillage impact on soil hydraulic properties. Soil Tillage Res. 170, 38-42.

Blouin, M., Hodson, M.E., Delgado, E.A., Baker, G., Brussaard, L., Butt, K.R., Dai, J., Dendooven, L., Peres, G., Tondoh, J.E., Cluzeau, D., Brun, J.-J., 2013. A review of earthworm impact on soil function and ecosystem services: Earthworm impact on ecosystem services. Eur. J. Soil Sci. 64, 161-182.

Blume, H.-P., Stahr, K., Leinweber, P., 2010. Bodenkundliches Praktikum: Eine Einführung in pedologisches Arbeiten für Ökologen, Land- und Forstwirte, Geo- und Umweltwissenschaftler, 3rd ed. Springer Spektrum, Heidelberg.

Bodhinayake, W., Si, B.C., 2004. Near-saturated surface soil hydraulic properties under different land uses in the St Denis National Wildlife Area, Saskatchewan, Canada. Hydrol. Process. 18, 2835-2850.

Bolger, A.M., Lohse, M., Usadel, B., 2014. Trimmomatic: a flexible trimmer for Illumina sequence data. Bioinforma. Oxf. Engl. 30, 2114-2120.

Bolyen, E., Rideout, J.R., Dillon, M.R., Bokulich, N.A., Abnet, C.C., Al-Ghalith, G.A., Alexander, H., Alm, E.J., Arumugam, M., Asnicar, F., Bai, Y., Bisanz, J.E., Bittinger, K., Brejnrod, A., Brislawn, C.J., Brown, C.T., Callahan, B.J., Caraballo-Rodríguez, A.M., Chase, J., Cope, E.K., Da Silva, R., Diener, C., Dorrestein, P.C., Douglas, G.M., Durall, D.M., Duvallet, C., Edwardson, C.F., Ernst, M., Estaki, M., Fouquier, J.,

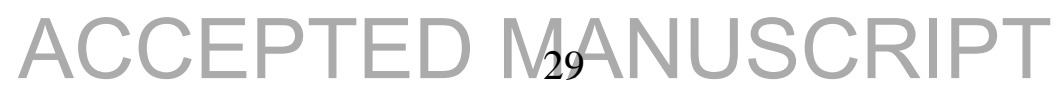


Gauglitz, J.M., Gibbons, S.M., Gibson, D.L., Gonzalez, A., Gorlick, K., Guo, J., Hillmann, B., Holmes, S., Holste, H., Huttenhower, C., Huttley, G.A., Janssen, S., Jarmusch, A.K., Jiang, L., Kaehler, B.D., Kang, K.B., Keefe, C.R., Keim, P., Kelley, S.T., Knights, D., Koester, I., Kosciolek, T., Kreps, J., Langille, M.G.I., Lee, J., Ley, R., Liu, Y.-X., Loftfield, E., Lozupone, C., Maher, M., Marotz, C., Martin, B.D., McDonald, D., McIver, L.J., Melnik, A.V., Metcalf, J.L., Morgan, S.C., Morton, J.T., Naimey, A.T., Navas-Molina, J.A., Nothias, L.F., Orchanian, S.B., Pearson, T., Peoples, S.L., Petras, D., Preuss, M.L., Pruesse, E., Rasmussen, L.B., Rivers, A., Robeson, M.S., Rosenthal, P., Segata, N., Shaffer, M., Shiffer, A., Sinha, R., Song, S.J., Spear, J.R., Swafford, A.D., Thompson, L.R., Torres, P.J., Trinh, P., Tripathi, A., Turnbaugh, P.J., Ul-Hasan, S., van der Hooft, J.J.J., Vargas, F., Vázquez-Baeza, Y., Vogtmann, E., von Hippel, M., Walters, W., Wan, Y., Wang, M., Warren, J., Weber, K.C., Williamson, C.H.D., Willis, A.D., Xu, Z.Z., Zaneveld, J.R., Zhang, Y., Zhu, Q., Knight, R., Caporaso, J.G., 2019. Reproducible, interactive, scalable and extensible microbiome data science using QIIME 2. Nat. Biotechnol. 37, 852-857.

Bouché, M.B., 1977. Strategies lombriciennes. Ecol. Bull., Soil Organisms as Components of Ecosystems 25, 122-132.

Burri, K., Graf, F., Böll, A., 2009. Revegetation measures improve soil aggregate stability: a case study of a landslide area in Central Switzerland. Snow Landsc Res 16.

Camacho, C., Coulouris, G., Avagyan, V., Ma, N., Papadopoulos, J., Bealer, K., Madden, T.L., 2009. BLAST+: architecture and applications. BMC Bioinformatics 10, 421.

Campbell, C.D., Chapman, S.J., Cameron, C.M., Davidson, M.S., Potts, J.M., 2003. A rapid microtiter plate method to measure carbon dioxide evolved from carbon substrate amendments so as to determine the physiological profiles of soil microbial communities by using whole soil. Appl Env. Microbiol 69, 3593-3599.

Carter, D.L., Blair, J.M., 2012. High richness and dense seeding enhance grassland restoration establishment but have little effect on drought response. Ecol. Appl. 22, 1308-1319.

Chauvat, M., Perez, G., Ponge, J.-F., 2014. Foraging patterns of soil springtails are impacted by food resources. Appl. Soil Ecol. 82, 72-77.

Chenu, C., 1989. Influence of a fungal polysaccharide, scleroglucan, on clay microstructures. Soil Biol. Biochem. 21, 299-305.

Christensen, B.T., Rasmussen, J., Eriksen, J., Hansen, E.M., 2009. Soil carbon storage and yields of spring barley following grass leys of different age. Eur. J. Agron. 31, 29-35.

Cluzeau, D., Guernion, M., Chaussod, R., Martin-Laurent, F., Villenave, C., Cortet, J., RuizCamacho, N., Pernin, C., Mateille, T., Philippot, L., Bellido, A., Rougé, L., Arrouays, D., Bispo, A., Pérès, G., 2012. Integration of biodiversity in soil quality monitoring: Baselines for microbial and soil fauna parameters for different land-use types. Eur. J. Soil Biol., Bioindication in Soil Ecosystems 49, 63-72.

Conant, R.T., Cerri, C.E.P., Osborne, B.B., Paustian, K., 2017. Grassland management impacts on soil carbon stocks: a new synthesis. Ecol. Appl. 27, 662-668.

Crème, A., Rumpel, C., Le Roux, X., Romian, A., Lan, T., Chabbi, A., 2018. Ley grassland under temperate climate had a legacy effect on soil organic matter quantity, biogeochemical signature and microbial activities. Soil Biol. Biochem. 122, 203-210.

Crotty, F.V., Fychan, R., Sanderson, R., Rhymes, J.R., Bourdin, F., Scullion, J., Marley, C.L., 2016. Understanding the legacy effect of previous forage crop and tillage management on soil biology, after conversion to an arable crop rotation. Soil Biol. Biochem. 103, 241-252.

Dominati, E., Patterson, M., Mackay, A., 2010. A framework for classifying and quantifying the natural capital and ecosystem services of soils. Ecol. Econ. 69, 1858-1868.

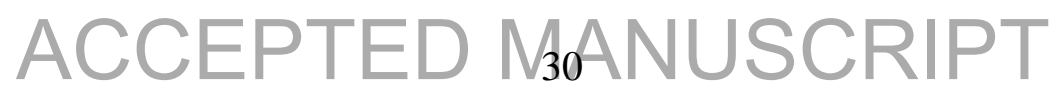


Dumbrell, A.J., Ashton, P.D., Aziz, N., Feng, G., Nelson, M., Dytham, C., Fitter, A.H., Helgason, T., 2011. Distinct seasonal assemblages of arbuscular mycorrhizal fungi revealed by massively parallel pyrosequencing. New Phytol. 190, 794-804.

Eijsackers, H., 2011. Earthworms as colonizers of natural and cultivated soil environments. Appl. Soil Ecol. 50, 1-13.

Endlweber, K., Ruess, L., Scheu, S., 2009. Collembola switch diet in presence of plant roots thereby functioning as herbivores. Soil Biol. Biochem. 41, 1151-1154.

Environmental Protection Agency, 1997. Methods for chemical analysis of water and wastes. Environmental Protection Agency, Cincinnati, Ohio.

Ewels, P., Magnusson, M., Lundin, S., Käller, M., 2016. MultiQC: summarize analysis results for multiple tools and samples in a single report. Bioinformatics 32, 3047-3048.

FAO, 2019. Conservation Agriculture [WWW Document]. Food Agric. Organ. U. N. URL http://www.fao.org/conservation-agriculture/en/ (accessed 12.10.19).

Fattet, M., Fu, Y., Ghestem, M., Ma, W., Foulonneau, M., Nespoulous, J., Le Bissonnais, Y., Stokes, A., 2011. Effects of vegetation type on soil resistance to erosion: Relationship between aggregate stability and shear strength. CATENA 87, 60-69.

Fay, P.A., Carlisle, J.D., Knapp, A.K., Blair, J.M., Collins, S.L., 2003. Productivity responses to altered rainfall patterns in a C4-dominated grassland. Oecologia 137, 245-251.

Filser, J., 2002. The role of Collembola in carbon and nitrogen cycling in soil. Pedobiologia 46, 234.

Fischer, C., Roscher, C., Jensen, B., Eisenhauer, N., Baade, J., Attinger, S., Scheu, S., Weisser, W.W., Schumacher, J., Hildebrandt, A., 2014. How Do Earthworms, Soil Texture and Plant Composition Affect Infiltration along an Experimental Plant Diversity Gradient in Grassland? PLoS ONE 9.

Fjellberg, A., 2007. The Collembola of Fennoscandia and Denmark, Part II: Entomobryomorpha and Symphypleona. Brill.

Fjellberg, A., 1998. The Collembola of Fennoscandia and Denmark, Part I: Poduromorpha. Brill.

Foley, J.A., Ramankutty, N., Brauman, K.A., Cassidy, E.S., Gerber, J.S., Johnston, M., Mueller, N.D., O’Connell, C., Ray, D.K., West, P.C., Balzer, C., Bennett, E.M., Carpenter, S.R., Hill, J., Monfreda, C., Polasky, S., Rockström, J., Sheehan, J., Siebert, S., Tilman, D., Zaks, D.P.M., 2011. Solutions for a cultivated planet. Nature 478, 337-342.

French, K.E., Tkacz, A., Turnbull, L.A., 2017. Conversion of grassland to arable decreases microbial diversity and alters community composition. Appl. Soil Ecol. 110, 43-52.

Gajda, Ł., Gorgoń, S., Urbisz, A.Z., 2017. Food preferences of enchytraeids. Pedobiologia 63, $19-36$.

Gange, A., 2000. Arbuscular mycorrhizal fungi, Collembola and plant growth. Trends Ecol. Evol. 15, 369-372.

Gazol, A., Zobel, M., Cantero, J.J., Davison, J., Esler, K.J., Jairus, T., Öpik, M., Vasar, M., Moora, M., 2016. Impact of alien pines on local arbuscular mycorrhizal fungal communities-evidence from two continents. FEMS Microbiol. Ecol. 92, fiw073.

Giller, K.E., Andersson, J.A., Corbeels, M., Kirkegaard, J., Mortensen, D., Erenstein, O., Vanlauwe, B., 2015. Beyond conservation agriculture. Front. Plant Sci. 6.

Gonzalez-Sosa, E., Braud, I., Dehotin, J., Lassabatère, L., Angulo-Jaramillo, R., Lagouy, M., Branger, F., Jacqueminet, C., Kermadi, S., Michel, K., 2010. Impact of land use on the hydraulic properties of the topsoil in a small French catchment. Hydrol. Process. 24, 2382-2399.

Graefe, U., Schmelz, R.M., 1999. Indicator values, strategy types and life forms of terrestrial Enchytraeidae and other microannelids. Newsl. Enchytraeidae 6, 59-67.

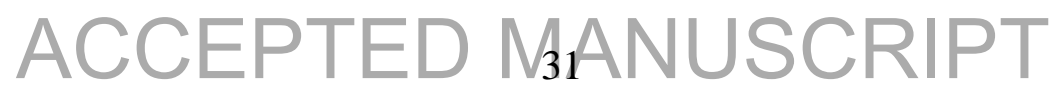


Graux, A.-I., Resmond, R., Casellas, E., Delaby, L., Faverdin, P., Le Bas, C., Ripoche, D., Ruget, F., Thérond, O., Vertès, F., Peyraud, J.-L., 2020. High-resolution assessment of French grassland dry matter and nitrogen yields. Eur. J. Agron. 112, 125952.

Gurr, G.M., Lu, Z., Zheng, X., Xu, H., Zhu, P., Chen, G., Yao, X., Cheng, J., Zhu, Z., Catindig, J.L., Villareal, S., Van Chien, H., Cuong, L.Q., Channoo, C., Chengwattana, N., Lan, L.P., Hai, L.H., Chaiwong, J., Nicol, H.I., Perovic, D.J., Wratten, S.D., Heong, K.L., 2016. Multi-country evidence that crop diversification promotes ecological intensification of agriculture. Nat. Plants 2, 1-4.

Hoeffner, K., Monard, C., Santonja, M., Cluzeau, D., 2018. Feeding behaviour of epi-anecic earthworm species and their impacts on soil microbial communities. Soil Biol. Biochem. 125, 1-9.

Hoeffner, K., Santonja, M., Cluzeau, D., Monard, C., 2019. Epi-anecic rather than strictanecic earthworms enhance soil enzymatic activities. Soil Biol. Biochem. 132, 93100.

Hopkin, S.P., 2007. A key to the springtails (Collembola) of Britain and Ireland. Field Stud. Counc. AIDGAP Proj. 245.

Hossain, M.Z., Okubo, A., Sugiyama, S., 2010. Effects of grassland species on decomposition of litter and soil microbial communities. Ecol. Res. 25, 255-261.

Hu, F., Gan, Y., Cui, H., Zhao, C., Feng, F., Yin, W., Chai, Q., 2016. Intercropping maize and wheat with conservation agriculture principles improves water harvesting and reduces carbon emissions in dry areas. Eur. J. Agron. 74, 9-17.

ISO, 2019. Soil quality - Sampling of soil invertebrates - Part 3: Sampling and extraction of enchytraeids. ISO 23611-3.

ISO, 2018. Soil quality - Sampling of soil invertebrates - Part 1: Hand-sorting and extraction of earthworms. ISO 23611-1.

ISO, 2012. Soil quality - Measurement of the stability of soil aggregates subjected to the action of water. ISO 10930.

ISO, 2006. Soil quality - Sampling of soil invertebrates - Part 2: Sampling and extraction of micro-arthropods (Collembola and Acarina). ISO 23611-2.

IUSS Working Group, W.R.B., 2015. World Reference Base for Soil Resources 2014, update 2015. International soil classification system for naming soils and creating legends for soil maps. (No. 106), World Soil Resources Reports. FAO, Rome.

Jänsch, S., Römbke, J., Didden, W., 2005. The use of enchytraeids in ecological soil classification and assessment concepts. Ecotoxicol. Environ. Saf., Includes Special Issue: Ecological soil quality 62, 266-277.

Janvier, C., Villeneuve, F., Alabouvette, C., Edel-Hermann, V., Mateille, T., Steinberg, C., 2007. Soil health through soil disease suppression: Which strategy from descriptors to indicators? Soil Biol. Biochem. 39, 1-23.

Jarvis, N., Koestel, J., Messing, I., Moeys, J., Lindahl, A., 2013. Influence of soil, land use and climatic factors on the hydraulic conductivity of soil. Hydrol. Earth Syst. Sci. Discuss. 10.

Jiménez-Fernández, D., Olivares-García, C., Trapero-Casas, J.L., Requena, J., Moreno, J., Jiménez-Díaz, R.M., 2015. Symptomless host and nonhost responses of Paulownia (Paulownia spp.) to olive-defoliating Verticillium dahliae. Plant Dis. 99, 962-968.

Joergensen, R.G., Mueller, T., 1996. The fumigation-extraction method to estimate soil microbial biomass: Calibration of the kEN value. Soil Biol. Biochem. 28, 33-37.

Jones, J., Woltz, S., 1972. Effect of soil pH and micronutrient amendments on Verticillium and Fusarium wilt of tomato. Plant Dis. Report. 56, 151-153.

Kempson, D., Lloyd, M., Ghelardi, R., 1963. A new extractor for woodland litter. Pedobiologia 3, 1-21.

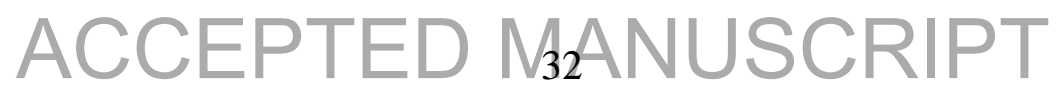


Knapp, S., van der Heijden, M.G.A., 2018. A global meta-analysis of yield stability in organic and conservation agriculture. Nat. Commun. 9, 1-9.

Konig, N., Fortmann, H., 1996. Probenvorbereitungs-, Untersuchungsund Elementbestimmungs-Methoden des Umweltanalytik-Labors der Niedersachsischen Forstlichen Versuchsanstalt, 1-4. Berichte Forschungszentrums Waldokosysteme Reihe B Univ. Gottingen.

Korthals, G.W., Thoden, T.C., van den Berg, W., Visser, J.H.M., 2014. Long-term effects of eight soil health treatments to control plant-parasitic nematodes and Verticillium dahliae in agro-ecosystems. Appl. Soil Ecol. 76, 112-123.

Kunrath, T.R., de Berranger, C., Charrier, X., Gastal, F., de Faccio Carvalho, P.C., Lemaire, G., Emile, J.-C., Durand, J.-L., 2015. How much do sod-based rotations reduce nitrate leaching in a cereal cropping system? Agric. Water Manag. 150, 46-56.

Lamandé, M., Hallaire, V., Curmi, P., Pérès, G., Cluzeau, D., 2003. Changes of pore morphology, infiltration and earthworm community in a loamy soil under different agricultural managements. CATENA, Achievements in Micromorphology 54, 637649.

Lassabatère, L., Angulo-Jaramillo, R., Soria Ugalde, J.M., Cuenca, R., Braud, I., Haverkamp, R., 2006. Beerkan estimation of soil transfer parameters through infiltration experiments-BEST. Soil Sci. Soc. Am. J. 70, 521-532.

Le Bissonnais, Y., 1996. Aggregate stability and assessment of soil crustability and erodibility: I. Theory and methodology. Eur. J. Soil Sci. 47, 425-437.

Lee, J., Lee, S., Young, J.P.W., 2008. Improved PCR primers for the detection and identification of arbuscular mycorrhizal fungi. FEMS Microbiol. Ecol. 65, 339-349.

Lehmann, A., Zheng, W., Rillig, M.C., 2017. Soil biota contributions to soil aggregation. Nat. Ecol. Evol. 1, 1828-1835.

Lemaire, G., Gastal, F., Franzluebbers, A., Chabbi, A., 2015. Grassland-cropping rotations: An avenue for agricultural diversification to reconcile high production with environmental quality. Environ. Manage. 56, 1065-1077.

Linsler, D., Taube, F., Geisseler, D., Joergensen, R.G., Ludwig, B., 2015. Temporal variations of the distribution of water-stable aggregates, microbial biomass and ergosterol in temperate grassland soils with different cultivation histories. Geoderma 241-242, 221-229.

Lipiec, J., Kuś, J., Słowińska-Jurkiewicz, A., Nosalewicz, A., 2006. Soil porosity and water infiltration as influenced by tillage methods. Soil Tillage Res. 89, 210-220.

Loaiza Puerta, V., Pujol Pereira, E.I., Wittwer, R., van der Heijden, M., Six, J., 2018. Improvement of soil structure through organic crop management, conservation tillage and grass-clover ley. Soil Tillage Res. 180, 1-9.

Maaß, S., Caruso, T., Rillig, M.C., 2015. Functional role of microarthropods in soil aggregation. Pedobiologia 58, 59-63.

Maathuis, F.J., 2009. Physiological functions of mineral macronutrients. Curr. Opin. Plant Biol., Physiology and Metabolism 12, 250-258.

Magoč, T., Salzberg, S.L., 2011. FLASH: fast length adjustment of short reads to improve genome assemblies. Bioinformatics 27, 2957-2963.

Marinissen, J.C.Y., Didden, W.A.M., 1997. Influence of the Enchytraeid worm Buchholzia appendiculata on aggregate formation and organic matter decomposition. Soil Biol. Biochem., 5th International Symposium on Earthworm Ecology 29, 387-390.

Martin, G., Durand, J.-L., Duru, M., Gastal, F., Julier, B., Litrico, I., Louarn, G., Médiène, S., Moreau, D., Valentin-Morison, M., Novak, S., Parnaudeau, V., Paschalidou, F., Vertès, F., Voisin, A.-S., Cellier, P., Jeuffroy, M.-H., 2020. Role of ley pastures in tomorrow's cropping systems. A review. Agron. Sustain. Dev. 40.

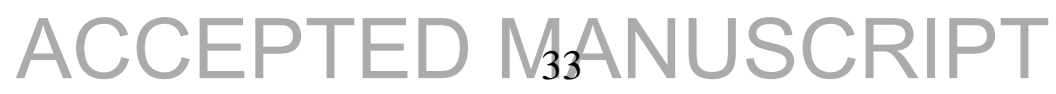


Mendes, L.W., Tsai, S.M., Navarrete, A.A., de Hollander, M., van Veen, J.A., Kuramae, E.E., 2015. Soil-borne microbiome: linking diversity to function. Microb. Ecol. 70, 255265.

Mommer, L., Cotton, T.E.A., Raaijmakers, J.M., Termorshuizen, A.J., Ruijven, J. van, Hendriks, M., Rijssel, S.Q. van, Mortel, J.E. van de, Paauw, J.W. van der, Schijlen, E.G.W.M., Smit-Tiekstra, A.E., Berendse, F., Kroon, H. de, Dumbrell, A.J., 2018. Lost in diversity: the interactions between soil-borne fungi, biodiversity and plant productivity. New Phytol. 218, 542-553.

Moni, C., Rumpel, C., Virto, I., Chabbi, A., Chenu, C., 2010. Relative importance of sorption versus aggregation for organic matter storage in subsoil horizons of two contrasting soils. Eur. J. Soil Sci. 61, 958-969.

Oehl, F., Sieverding, E., Ineichen, K., Mäder, P., Boller, T., Wiemken, A., 2003. Impact of land use intensity on the species diversity of arbuscular mycorrhizal fungi in agroecosystems of central Europe. Appl. Environ. Microbiol. 69, 2816-2824.

Opik, M., Vanatoa, A., Vanatoa, E., Moora, M., Davison, J., Kalwij, J.M., Reier, U., Zobel, M., 2010. The online database MaarjAM reveals global and ecosystemic distribution patterns in arbuscular mycorrhizal fungi (Glomeromycota). New Phytol. 188, 223241.

Panettieri, M., Rumpel, C., Dignac, M.-F., Chabbi, A., 2017. Does grassland introduction into cropping cycles affect carbon dynamics through changes of allocation of soil organic matter within aggregate fractions? Sci. Total Environ. 576, 251-263.

Parihar, C.M., Yadav, M.R., Jat, S.L., Singh, A.K., Kumar, B., Pradhan, S., Chakraborty, D., Jat, M.L., Jat, R.K., Saharawat, Y.S., Yadav, O.P., 2016. Long term effect of conservation agriculture in maize rotations on total organic carbon, physical and biological properties of a sandy loam soil in north-western Indo-Gangetic Plains. Soil Tillage Res. 161, 116-128.

Partsch, S., Milcu, A., Scheu, S., 2006. Decomposers (Lumbricidae, Collembola) affect plant performance in model grasslands of different diversity. Ecology 87, 2548-2558.

Pascault, N., Cécillon, L., Mathieu, O., Hénault, C., Sarr, A., Lévêque, J., Farcy, P., Ranjard, L., Maron, P.-A., 2010. In situ dynamics of microbial communities during decomposition of wheat, rape, and alfalfa residues. Microb. Ecol. 60, 816-828.

Pelosi, C., Barot, S., Capowiez, Y., Hedde, M., Vandenbulcke, F., 2013. Pesticides and earthworms. A review. Agron. Sustain. Dev. 34, 199-228.

Pérès, G., Bellido, A., Curmi, P., Marmonier, P., Cluzeau, D., 2010. Relationships between earthworm communities and burrow numbers under different land use systems. Pedobiologia 54, 37-44.

Pérès, G., Cluzeau, D., Menasseri, S., Soussana, J.F., Bessler, H., Engels, C., Habekost, M., Gleixner, G., Weigelt, A., Weisser, W.W., Scheu, S., Eisenhauer, N., 2013. Mechanisms linking plant community properties to soil aggregate stability in an experimental grassland plant diversity gradient. Plant Soil 373, 285-299.

Pittelkow, C.M., Liang, X., Linquist, B.A., van Groenigen, K.J., Lee, J., Lundy, M.E., van Gestel, N., Six, J., Venterea, R.T., van Kessel, C., 2015. Productivity limits and potentials of the principles of conservation agriculture. Nature 517, 365-368.

Postma, J., Schilder, M.T., Bloem, J., van Leeuwen-Haagsma, W.K., 2008. Soil suppressiveness and functional diversity of the soil microflora in organic farming systems. Soil Biol. Biochem., Special Section: Enzymes in the Environment 40, 23942406.

Postma-Blaauw, M.B., de Goede, R.G.M., Bloem, J., Faber, J.H., Brussaard, L., 2010. Soil biota community structure and abundance under agricultural intensification and extensification. Ecology 91, 460-473.

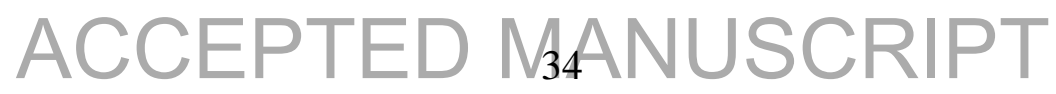


Powlson, D.S., Stirling, C.M., Jat, M.L., Gerard, B.G., Palm, C.A., Sanchez, P.A., Cassman, K.G., 2014. Limited potential of no-till agriculture for climate change mitigation. Nat. Clim. Change 4, 678-683.

Rampersad, S.N., 2010. A rapid colorimetric microtiter bioassay to evaluate fungicide sensitivity among Verticillium dahliae isolates. Plant Dis. 95, 248-255.

Reicosky, D.C., 2015. Conservation tillage is not conservation agriculture. J. Soil Water Conserv. 70, 103A-108A.

Rognes, T., Flouri, T., Nichols, B., Quince, C., Mahé, F., 2016. VSEARCH: a versatile open source tool for metagenomics. PeerJ 4, e2584.

Ros, M., Goberna, M., Moreno, J.L., Hernandez, T., García, C., Insam, H., Pascual, J.A., 2006. Molecular and physiological bacterial diversity of a semi-arid soil contaminated with different levels of formulated atrazine. Appl. Soil Ecol. 34, 93-102.

Rousk, J., Brookes, P.C., Bååth, E., 2009. Contrasting soil pH effects on fungal and bacterial growth suggest functional redundancy in carbon mineralization. Appl. Environ. Microbiol. 75, 1589-1596.

Scharenbroch, B.C., Lloyd, J.E., Johnson-Maynard, J.L., 2005. Distinguishing urban soils with physical, chemical, and biological properties. Pedobiologia 49, 283-296.

Scheunemann, N., Digel, C., Scheu, S., Butenschoen, O., 2015. Roots rather than shoot residues drive soil arthropod communities of arable fields. Oecologia 179, 1135-1145.

Schlatter, D., Kinkel, L., Thomashow, L., Weller, D., Paulitz, T., 2017. Disease suppressive soils: New insights from the soil microbiome. Phytopathology 107, 1284-1297.

Schwartz, R.C., Evett, S.R., Unger, P.W., 2003. Soil hydraulic properties of cropland compared with reestablished and native grassland. Geoderma, Quantifying agricultural management effects on soil properties and processes 116, 47-60.

Senapati, N., Chabbi, A., Giostri, A.F., Yeluripati, J.B., Smith, P., 2016. Modelling nitrous oxide emissions from mown-grass and grain-cropping systems: Testing and sensitivity analysis of DailyDayCent using high frequency measurements. Sci. Total Environ. 572, 955-977.

Seufert, V., Ramankutty, N., Foley, J.A., 2012. Comparing the yields of organic and conventional agriculture. Nature 485, 229-232.

Siddiky, Md.R.K., Schaller, J., Caruso, T., Rillig, M.C., 2012. Arbuscular mycorrhizal fungi and collembola non-additively increase soil aggregation. Soil Biol. Biochem. 47, 9399.

Sirimarco, X., Barral, M.P., Villarino, S.H., Laterra, P., 2018. Water regulation by grasslands: A global meta-analysis. Ecohydrology 11, e1934.

Souza, R.C., Hungria, M., Cantão, M.E., Vasconcelos, A.T.R., Nogueira, M.A., Vicente, V.A., 2015. Metagenomic analysis reveals microbial functional redundancies and specificities in a soil under different tillage and crop-management regimes. Appl. Soil Ecol. 86, 106-112.

Stauffer, M., Leyval, C., Brun, J.-J., Leportier, P., Berthelin, J., 2014. Effect of willow short rotation coppice on soil properties after three years of growth as compared to forest, grassland and arable land uses. Plant Soil 377, 423-438.

Swinton, S.M., Lupi, F., Robertson, G.P., Hamilton, S.K., 2007. Ecosystem services and agriculture: Cultivating agricultural ecosystems for diverse benefits. Ecol. Econ., Special Section - Ecosystem Services and Agriculture 64, 245-252.

Teague, W.R., Dowhower, S.L., Baker, S.A., Haile, N., DeLaune, P.B., Conover, D.M., 2011. Grazing management impacts on vegetation, soil biota and soil chemical, physical and hydrological properties in tall grass prairie. Agric. Ecosyst. Environ. 141, 310-322.

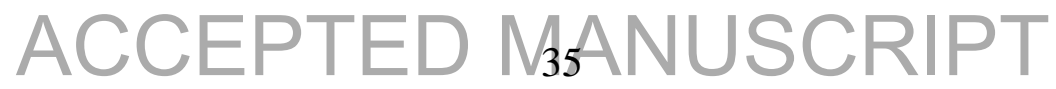


Toju, H., Tanabe, A.S., Yamamoto, S., Sato, H., 2012. High-coverage ITS primers for the DNA-based identification of Ascomycetes and Basidiomycetes in environmental samples. PLOS ONE 7, e40863.

Urbanová, M., Šnajdr, J., Baldrian, P., 2015. Composition of fungal and bacterial communities in forest litter and soil is largely determined by dominant trees. Soil Biol. Biochem. 84, 53-64.

Vályi, K., Rillig, M.C., Hempel, S., 2015. Land-use intensity and host plant identity interactively shape communities of arbuscular mycorrhizal fungi in roots of grassland plants. New Phytol. 205, 1577-1586.

van Capelle, C., Schrader, S., Brunotte, J., 2012. Tillage-induced changes in the functional diversity of soil biota - A review with a focus on German data. Eur. J. Soil Biol. 50, $165-181$.

van Eekeren, N., Bommelé, L., Bloem, J., Schouten, T., Rutgers, M., de Goede, R., Reheul, D., Brussaard, L., 2008. Soil biological quality after 36 years of ley-arable cropping, permanent grassland and permanent arable cropping. Appl. Soil Ecol. 40, 432-446.

Vance, E.D., Brookes, P.C., Jenkinson, D.S., 1987. An extraction method for measuring soil microbial biomass C. Soil Biol. Biochem. 19, 703-707.

Vandewalle, M., de Bello, F., Berg, M.P., Bolger, T., Dolédec, S., Dubs, F., Feld, C.K., Harrington, R., Harrison, P.A., Lavorel, S., da Silva, P.M., Moretti, M., Niemelä, J., Santos, P., Sattler, T., Sousa, J.P., Sykes, M.T., Vanbergen, A.J., Woodcock, B.A., 2010. Functional traits as indicators of biodiversity response to land use changes across ecosystems and organisms. Biodivers. Conserv. 19, 2921-2947.

Vasar, M., Davison, J., Neuenkamp, L., Sepp, S.-K., Young, J.P.W., Moora, M., Öpik, M., 2021. User-friendly bioinformatics pipeline gDAT (graphical downstream analysis tool) for analysing rDNA sequences. Mol. Ecol. Resour.

Walters, W., Hyde, E.R., Berg-Lyons, D., Ackermann, G., Humphrey, G., Parada, A., Gilbert, J.A., Jansson, J.K., Caporaso, J.G., Fuhrman, J.A., Apprill, A., Knight, R., 2016. Improved bacterial 16S rRNA gene (V4 and V4-5) and fungal internal transcribed spacer marker gene primers for microbial community surveys. mSystems 1 .

Wardle, D.A., 1992. A comparative assessment of factors which influence microbial biomass carbon and nitrogen levels in soil. Biol. Rev. 67, 321-358.

Weiler, M., Naef, F., 2003. An experimental tracer study of the role of macropores in infiltration in grassland soils. Hydrol. Process. 17, 477-493.

Weller, D.M., Raaijmakers, J.M., Gardener, B.B.M., Thomashow, L.S., 2002. Microbial populations responsible for specific soil suppressiveness to plant pathogens. Annu. Rev. Phytopathol. 40, 309-348.

Wolters, V., 1991. Soil invertebrates - Effects on nutrient turnover and soil structure - a review. Z. Pflanzenernahrung Bodenkd. 154, 389-402.

Wu, J., O’donnell, A.G., He, Z.L., Syers, J.K., 1994. Fumigation-extraction method for the measurement of soil microbial biomass-S. Soil Biol. Biochem. 26, 117-125. 


\section{TABLES}

Table 1. Experimental design of the study site with the 3 treatments. Annual crops only (AC), grassland with medium percentage $(50 \%)$ of grassland in the rotation $(3 \mathrm{G})$ and grassland with high percentage $(75 \%)$ of grassland in the rotation $(6 \mathrm{G})$. The vertical bold line indicates the date of sampling (April 2017).

\begin{tabular}{lllllllllllll|l}
\hline & 2005 & 2006 & 2007 & 2008 & 2009 & 2010 & 2011 & 2012 & 2013 & 2014 & 2015 & 2016 & 2017 \\
\hline AC & Maize & Wheat & Barley & Maize & Wheat & Barley & Maize & Wheat & Barley & Maize & Wheat & Barley & Maize \\
3G & Maize & Wheat & Barley & & Grassland & Maize & Wheat & Barley & & Grassland & Maize \\
6G & & & Grassland & & & Maize & Wheat & Barley & & Grassland & \\
\hline
\end{tabular}


Table 2. Mean values \pm standard errors of selected soil variables: carbon $\left(\mathrm{mg} \cdot \mathrm{g}^{-1}\right)$, nitrogen $\left(\mathrm{mg} \cdot \mathrm{g}^{-1}\right)$, phosphorus $\left(\mathrm{mg} \cdot \mathrm{g}^{-1}\right)$, cation-exchange capacity $\left(\mathrm{CEC}, \mathrm{mmol} \cdot \mathrm{kg}^{-1}\right), \mathrm{pH}$ (water), water content (WC, \%), bulk density $\left(\mathrm{g} \cdot \mathrm{cm}^{-3}\right)$, clay $(\%)$, silt $(\%)$ and sand $(\%)$ by experimental treatment $(n=4)$. Annual crops only $(A C)$, grassland with medium percentage $(50 \%)$ of grassland in the rotation $(3 \mathrm{G})$ and grassland with high percentage $(75 \%)$ of grassland in the rotation (6G). Sampling was performed in 2017 except for the bulk density which was performed in 2016. Different letters denote significant differences between treatments with a $>$ b (Tukey HSD test) at $\mathrm{P}<0.05$ level. $\chi^{2}$-values and associated $P$-values are indicated.

\begin{tabular}{|c|c|c|c|c|c|c|c|c|}
\hline & & \multicolumn{5}{|l|}{ Treatments } & \multicolumn{2}{|c|}{ Blocks } \\
\hline & & $\mathrm{AC}$ & $3 \mathrm{G}$ & $6 \mathrm{G}$ & $\chi^{2}$ & $P$ & $\chi^{2}$ & $P$ \\
\hline \multirow[t]{2}{*}{ Carbon } & $0-10 \mathrm{~cm}$ & $12.5^{\mathrm{b}} \pm 0.7$ & $14.4^{a} \pm 0.6$ & $14.5^{a} \pm 0.6$ & 13.77 & 0.006 & 10.61 & 0.008 \\
\hline & $10-20 \mathrm{~cm}$ & $11.7^{b} \pm 0.8$ & $12.4^{b} \pm 0.5$ & $14.1^{\mathrm{a}} \pm 0.9$ & 16.43 & 0.004 & 15.86 & 0.003 \\
\hline \multirow[t]{2}{*}{ Nitrogen } & $0-10 \mathrm{~cm}$ & $1.28^{b} \pm 0.05$ & $1.43^{\mathrm{a}} \pm 0.03$ & $1.48^{\mathrm{a}} \pm 0.03$ & 19.50 & 0.002 & 4.38 & 0.059 \\
\hline & $10-20 \mathrm{~cm}$ & $1.25^{b} \pm 0.05$ & $1.30^{\mathrm{ab}} \pm 0.04$ & $1.45^{\mathrm{a}} \pm 0.06$ & 7.80 & 0.021 & 4.00 & 0.070 \\
\hline \multirow[t]{2}{*}{ Phosphorus } & $0-10 \mathrm{~cm}$ & $0.71^{\mathrm{a}} \pm 0.05$ & $0.69^{a} \pm 0.06$ & $0.71^{a} \pm 0.05$ & 0.71 & 0.528 & 29.74 & $<0.001$ \\
\hline & $10-20 \mathrm{~cm}$ & $0.72^{\mathrm{a}} \pm 0.05$ & $0.70^{a} \pm 0.03$ & $0.69^{\mathrm{a}} \pm 0.04$ & 0.35 & 0.720 & 6.52 & 0.026 \\
\hline \multirow[t]{2}{*}{ CEC } & $0-10 \mathrm{~cm}$ & $75.2^{\mathrm{a}} \pm 5.7$ & $69.4^{\mathrm{a}} \pm 6.1$ & $69.9^{a} \pm 2.6$ & 1.10 & 0.392 & 6.24 & 0.028 \\
\hline & $10-20 \mathrm{~cm}$ & $67.7^{\mathrm{a}} \pm 7.4$ & $64.3^{a} \pm 5.2$ & $71.0^{\mathrm{a}} \pm 2.3$ & 0.33 & 0.733 & 0.53 & 0.679 \\
\hline \multirow{2}{*}{$\mathrm{pH}$} & $0-10 \mathrm{~cm}$ & $6.2^{\mathrm{a}} \pm 0.2$ & $5.9^{\mathrm{ab}} \pm 0.1$ & $5.5^{b} \pm 0.1$ & 10.36 & 0.011 & 2.25 & 0.183 \\
\hline & $10-20 \mathrm{~cm}$ & $6.1^{\mathrm{a}} \pm 0.1$ & $6.0^{\mathrm{a}} \pm 0.1$ & $5.8^{\mathrm{a}} \pm 0.1$ & 0.81 & 0.489 & 0.43 & 0.736 \\
\hline \multirow[t]{2}{*}{ WC } & $0-10 \mathrm{~cm}$ & $18.8^{\mathrm{a}} \pm 0.7$ & $20.8^{\mathrm{a}} \pm 1.0$ & $20.4^{a} \pm 0.3$ & 2.11 & 0.203 & 1.06 & 0.432 \\
\hline & $10-20 \mathrm{~cm}$ & $17.9^{b} \pm 0.7$ & $19.0^{\mathrm{a}} \pm 0.4$ & $19.9^{a} \pm 0.5$ & 6.73 & 0.004 & 1.60 & 0.210 \\
\hline Bulk density & $0-30 \mathrm{~cm}$ & $1.50^{\mathrm{a}} \pm 0.01$ & $1.52^{\mathrm{a}} \pm 0.01$ & $1.51^{\mathrm{a}} \pm 0.02$ & 0.11 & 0.896 & 0.10 & 0.954 \\
\hline Clay & $0-30 \mathrm{~cm}$ & $19.1^{\mathrm{a}} \pm 1.2$ & $16.5^{\mathrm{a}} \pm 1.9$ & $18.3^{a} \pm 0.9$ & 1.75 & 0.251 & 0.40 & 0.760 \\
\hline Silt & $0-30 \mathrm{~cm}$ & $65.7^{\mathrm{a}} \pm 2.7$ & $66.6^{\mathrm{a}} \pm 2.1$ & $64.9^{\mathrm{a}} \pm 4.1$ & 0.24 & 0.794 & 3.30 & 0.099 \\
\hline Sand & $0-30 \mathrm{~cm}$ & $15.2^{\mathrm{a}} \pm 2.4$ & $17.0^{\mathrm{a}} \pm 3.2$ & $16.8^{a} \pm 3.9$ & 1.04 & 0.409 & 13.21 & 0.005 \\
\hline
\end{tabular}


Table 3. Mean values \pm standard errors of soil aggregate stability measured with SW-slow wetting $(\mathrm{mm})$, FW-fast wetting $(\mathrm{mm})$ and MB-mechanical breakdown $(\mathrm{mm})$ as well as saturated hydraulic conductivity rate $\left(\mathrm{mm} \mathrm{s}^{-1}\right)$ by experimental treatment $(\mathrm{n}=4)$. Annual crops only (AC), grassland with medium percentage $(50 \%)$ of grassland in the rotation $(3 \mathrm{G})$ and grassland with high percentage (75\%) of grassland in the rotation (6G). Different letters denote significant differences between treatments with $\mathrm{a}>\mathrm{b}$ (Tukey HSD test) at $\mathrm{P}<0.05$ level. $\chi^{2}$-values and associated $P$-values are indicated.

\begin{tabular}{|c|c|c|c|c|c|c|c|c|}
\hline & & \multicolumn{5}{|l|}{ Treatments } & \multicolumn{2}{|c|}{ Blocks } \\
\hline \multirow{3}{*}{ Slow wetting } & & $\mathrm{AC}$ & $3 \mathrm{G}$ & $6 \mathrm{G}$ & $\chi^{2}$ & $P$ & $\chi^{2}$ & $P$ \\
\hline & $0-10 \mathrm{~cm}$ & $0.43^{\mathrm{a}} \pm 0.04$ & $0.72^{b} \pm 0.07$ & $0.70^{b} \pm 0.03$ & 9.83 & 0.007 & 0.03 & 0.875 \\
\hline & $10-20 \mathrm{~cm}$ & $0.50^{\mathrm{a}} \pm 0.06$ & $0.57^{\mathrm{a}} \pm 0.12$ & $0.66^{\mathrm{a}} \pm 0.06$ & 0.83 & 0.470 & 0.11 & 0.751 \\
\hline \multirow[t]{2}{*}{ Fast wetting } & $0-10 \mathrm{~cm}$ & $0.35^{\mathrm{a}} \pm 0.02$ & $0.50^{\mathrm{a}} \pm 0.06$ & $0.45^{\mathrm{a}} \pm 0.03$ & 3.96 & 0.064 & 2.16 & 0.180 \\
\hline & $10-20 \mathrm{~cm}$ & $0.35^{\mathrm{a}} \pm 0.02$ & $0.50^{\mathrm{a}} \pm 0.09$ & $0.43^{\mathrm{a}} \pm 0.04$ & 2.43 & 0.150 & 5.23 & 0.052 \\
\hline \multirow{2}{*}{ Mechanical breakdown } & $0-10 \mathrm{~cm}$ & $1.45^{\mathrm{a}} \pm 0.08$ & $1.41^{\mathrm{a}} \pm 0.12$ & $1.54^{\mathrm{a}} \pm 0.07$ & 0.47 & 0.639 & 0.83 & 0.389 \\
\hline & $10-20 \mathrm{~cm}$ & $1.46^{\mathrm{b}} \pm 0.09$ & $1.56^{\mathrm{b}} \pm 0.04$ & $1.86^{\mathrm{a}} \pm 0.05$ & 9.11 & 0.009 & 0.15 & 0.706 \\
\hline \multicolumn{2}{|c|}{ Saturated hydraulic conductivity $\left(\mathrm{E}^{-02}\right)$} & $1.31^{\mathrm{a}} \pm 0.23$ & $1.19^{\mathrm{a}} \pm 0.18$ & $1.60^{\mathrm{a}} \pm 0.18$ & 0.62 & 0.564 & 0.51 & 0.497 \\
\hline
\end{tabular}


Table 4. Mean values \pm standard errors of bacterial, fungal richness and evenness indexes, AMF (arbuscular mycorrhizal fungi) sample-based abundance (sequence number per sample), richness and evenness indexes, and microbial biomass by experimental treatment $(n=24)$. Annual crops only (AC), grassland with medium percentage $(50 \%)$ of grassland in the rotation $(3 \mathrm{G})$ and grassland with high percentage $(75 \%)$ of grassland in the rotation $(6 \mathrm{G})$. Different letters denote significant differences between treatments with $a>b$ (Tukey HSD test) at $\mathrm{P}<0.05$ level. $\chi^{2}$-values and associated $P$-values are indicated.

\begin{tabular}{|c|c|c|c|c|c|c|c|c|}
\hline & & \multicolumn{5}{|l|}{ Treatments } & \multicolumn{2}{|c|}{ Blocks } \\
\hline \multirow{3}{*}{ Bacteria } & & $\mathrm{AC}$ & $3 G$ & $6 \mathrm{G}$ & $\chi^{2}$ & $P$ & $\chi^{2}$ & $P$ \\
\hline & Richness & $60.9^{\mathrm{a}} \pm 3.9$ & $51.0^{\mathrm{a}} \pm 4.4$ & $56.7^{\mathrm{a}} \pm 4.5$ & 3.91 & 0.142 & 0.02 & 0.881 \\
\hline & Eveness & $0.95^{\mathrm{a}} \pm 0.00$ & $0.95^{\mathrm{a}} \pm 0.01$ & $0.95^{\mathrm{a}} \pm 0.00$ & 0.53 & 0.769 & 0.10 & 0.752 \\
\hline \multirow[t]{2}{*}{ Fungi } & Richness & $181.2^{\mathrm{a}} \pm 9.9$ & $146.3^{a} \pm 5.3$ & $164.1^{a} \pm 6.9$ & 5.22 & 0.074 & 1.42 & 0.234 \\
\hline & Eveness & $0.78^{a} \pm 0.01$ & $0.75^{\mathrm{a}} \pm 0.02$ & $0.75^{\mathrm{a}} \pm 0.02$ & 2.02 & 0.364 & 0.35 & 0.555 \\
\hline \multirow[t]{3}{*}{ AMF } & Abundance & $529.2^{b} \pm 143.7$ & $1274.9^{\mathrm{a}} \pm 163.3$ & $1030.6^{\mathrm{ab}} \pm 198.2$ & 12.86 & 0.002 & 7.82 & 0.050 \\
\hline & Richness & $9.4^{b} \pm 1.3$ & $10.8^{\mathrm{ab}} \pm 0.7$ & $13.1^{\mathrm{a}} \pm 0.9$ & 7.51 & 0.023 & 12.04 & 0.007 \\
\hline & Eveness & $0.60^{\mathrm{ab}} \pm 0.04$ & $0.49^{b} \pm 0.04$ & $0.64^{\mathrm{a}} \pm 0.03$ & 10.35 & 0.006 & 3.25 & 0.355 \\
\hline \multirow{3}{*}{$\begin{array}{l}\text { Microbial } \\
\text { biomass }\end{array}$} & $0-10 \mathrm{~cm}$ & $144.5^{b} \pm 7.5$ & $171.7^{\mathrm{ab}} \pm 5.9$ & $206.2^{\mathrm{a}} \pm 18.5$ & 6.13 & 0.034 & 0.56 & 0.661 \\
\hline & $10-20 \mathrm{~cm}$ & $120.2^{b} \pm 3.1$ & $168.9^{\mathrm{a}} \pm 2.5$ & $181.1^{\mathrm{a}} \pm 10.1$ & 29.24 & $<0.001$ & 1.63 & 0.279 \\
\hline & $20-30 \mathrm{~cm}$ & $114.9^{b} \pm 10.1$ & $131.2^{b} \pm 10.0$ & $160.8^{\mathrm{a}} \pm 18.1$ & 11.63 & 0.009 & 10.15 & 0.009 \\
\hline
\end{tabular}


Table 5. Mean abundance (individuals $\mathrm{m}^{-2}$ ), richness and evenness index of springtails (a), enchytraeids (b) and earthworms (c) by experimental treatment $(\mathrm{n}=16) \pm$ standard errors. Annual crops only $($ AC), grassland with a medium percentage $(50 \%)$ of grassland in the rotation $(3 \mathrm{G})$ and grassland with a high percentage $(75 \%)$ of grassland in the rotation (6G). Different letters denote significant differences between treatments with a $>$ b (Tukey HSD test) at $\mathrm{P}<0.05$ level. $\chi^{2}$-values and associated $P$-values are indicated.

\begin{tabular}{|c|c|c|c|c|c|c|c|c|}
\hline & & \multicolumn{5}{|l|}{ Treatments } & \multicolumn{2}{|c|}{ Blocks } \\
\hline & & $\mathrm{AC}$ & $3 \mathrm{G}$ & $6 \mathrm{G}$ & $F$ & $P$ & $F$ & $P$ \\
\hline \multicolumn{9}{|c|}{ (a) Springtail } \\
\hline \multirow[t]{4}{*}{ Abundance } & Total & $12520^{a} \pm 2778$ & $11459^{\mathrm{a}} \pm 2567$ & $20033^{a} \pm 4194$ & 2.83 & 0.243 & 0.23 & 0.63 \\
\hline & Epi-edaphic & $5475^{\mathrm{ab}} \pm 2320$ & $2929^{b} \pm 753$ & $9974^{a} \pm 2764$ & 6.39 & 0.041 & 5.47 & 0.019 \\
\hline & Hemi-edaphic & $6069^{a} \pm 1543$ & $3311^{\mathrm{a}} \pm 1429$ & $5517^{a} \pm 3345$ & 2.55 & 0.279 & 8.74 & 0.003 \\
\hline & Eu-edaphic & $976^{b} \pm 323$ & $5520^{\mathrm{a}} \pm 1980$ & $4541^{\mathrm{a}} \pm 1284$ & 9.45 & 0.009 & 4.2 & 0.04 \\
\hline \multirow[t]{2}{*}{ Diversity } & Richness & $6.8^{\mathrm{ab}} \pm 0.7$ & $5.3^{b} \pm 0.6$ & $7.8^{\mathrm{a}} \pm 0.8$ & 6.61 & 0.037 & 0.81 & 0.367 \\
\hline & Eveness & $0.8^{\mathrm{a}} \pm 0.0$ & $0.8^{\mathrm{a}} \pm 0.0$ & $0.8^{\mathrm{a}} \pm 0.0$ & 0.34 & 0.842 & 1.99 & 0.158 \\
\hline \multicolumn{9}{|c|}{ (b) Enchytraeid } \\
\hline \multirow[t]{5}{*}{ Abundance } & Total & $16892^{a} \pm 3668$ & $9846^{\mathrm{a}} \pm 1460$ & $15194^{a} \pm 1773$ & 4.09 & 0.129 & 3.82 & 0.281 \\
\hline & Opportunisitic species & $3565^{\mathrm{a}} \pm 1158$ & $324^{b} \pm 151$ & $880^{\mathrm{ab}} \pm 209$ & 21.86 & $<0.001$ & 7.04 & 0.071 \\
\hline & Litter dweller & $0 \pm 0$ & $139^{b} \pm 95$ & $880^{\mathrm{a}} \pm 349$ & 4.76 & 0.002 & 0.18 & 0.91 \\
\hline & Soil dweller & $12131^{\mathrm{a}} \pm 2468$ & $8102^{a} \pm 1403$ & $12918^{\mathrm{a}} \pm 1602$ & 2.71 & 0.257 & 6.13 & 0.106 \\
\hline & Deepness dweller & $1343^{a} \pm 493$ & $556^{\mathrm{a}} \pm 180$ & $509^{a} \pm 218$ & 2.48 & 0.29 & 12.34 & 0.006 \\
\hline \multirow[t]{2}{*}{ Diversity } & Richness & $7.5^{\mathrm{a}} \pm 0.8$ & $6.5^{\mathrm{a}} \pm 0.6$ & $8.3^{a} \pm 0.5$ & 4.05 & 0.132 & 2.18 & 0.536 \\
\hline & Eveness & $0.8^{\mathrm{a}} \pm 0.0$ & $0.9^{\mathrm{a}} \pm 0.0$ & $0.9^{\mathrm{a}} \pm 0.0$ & 0.71 & 0.703 & 1.12 & 0.774 \\
\hline \multicolumn{9}{|c|}{ (c) Earthworm } \\
\hline \multirow[t]{5}{*}{ Abundance } & Total & $321^{b} \pm 57$ & $488^{a} \pm 40$ & $496^{\mathrm{a}} \pm 47$ & 11.11 & 0.003 & 0.66 & 0.882 \\
\hline & Epigeic & $57^{a} \pm 17$ & $76^{a} \pm 20$ & $83^{a} \pm 30$ & 0.09 & 0.957 & 3.62 & 0.306 \\
\hline & Epi-anecic & $26^{b} \pm 7$ & $70^{a} \pm 12$ & $64^{a} \pm 9$ & 25.86 & $<0.001$ & 6.4 & 0.093 \\
\hline & Strict-anecic & $42^{b} \pm 10$ & $141^{\mathrm{a}} \pm 21$ & $145^{\mathrm{a}} \pm 15$ & 22.23 & $<0.001$ & 0.05 & 0.997 \\
\hline & Endogeic & $195^{\mathrm{a}} \pm 39$ & $201^{\mathrm{a}} \pm 31$ & $204^{\mathrm{a}} \pm 21$ & 0.15 & 0.926 & 1.5 & 0.682 \\
\hline \multirow[t]{2}{*}{ Diversity } & Richness & $4.9^{b} \pm 0.2$ & $6.1^{\mathrm{a}} \pm 0.3$ & $6.4^{\mathrm{a}} \pm 0.3$ & 15.95 & $<0.001$ & 5.1 & 0.165 \\
\hline & Eveness & $0.9^{\mathrm{a}} \pm 0.0$ & $0.9^{\mathrm{a}} \pm 0.0$ & $0.9^{\mathrm{a}} \pm 0.0$ & 0.94 & 0.627 & 1.12 & 0.772 \\
\hline
\end{tabular}


Table 6. Mean values of soil suppressiveness associated variables by experimental treatment $(\mathrm{n}=12) \pm$ standard errors: final severity $(0-4)$, infected plants $(\%)$, plant height- $V$. dahliae $(\mathrm{cm})$, plant weight- $V$. dahliae $(\mathrm{g})$, plant height-control $(\mathrm{cm})$, plant weight-control $(\mathrm{g})$. Annual crops only (AC), grassland with medium percentage $(50 \%)$ of grassland in the rotation $(3 \mathrm{G})$ and grassland with high percentage (75\%) of grassland in the rotation (6G). Different letters denote significant differences between treatments with $\mathrm{a}>\mathrm{b}$ (Tukey HSD test) at $\mathrm{P}<0.05$ level. $F$-values and associated $P$-values are indicated.

\begin{tabular}{llllll}
\hline & AC & $3 G$ & $6 G$ & $F$ & $P$ \\
\hline Final severity & $0.33^{\mathrm{b}} \pm 0.23$ & $2.69^{\mathrm{a}} \pm 0.33$ & $2.42^{\mathrm{a}} \pm 0.45$ & 17.25 & $<0.001$ \\
Infected plants & $16.67^{\mathrm{b}} \pm 7.82$ & $98.33^{\mathrm{a}} \pm 7.82^{\mathrm{a}}$ & $90.48^{\mathrm{a}} \pm 8.19$ & 32.85 & $<0.001$ \\
Plant height- $V$. dahliae & $53.18^{\mathrm{a}} \pm 4.56$ & $48.91^{\mathrm{a}} \pm 5.97$ & $47.58^{\mathrm{a}} \pm 6.82$ & 0.29 & 0.753 \\
Plant weigth- $V$. dahliae & $11.45^{\mathrm{a}} \pm 1.12$ & $8.55^{\mathrm{a}} \pm 1.66$ & $8.62^{\mathrm{a}} \pm 1.92$ & 1.30 & 0.287 \\
Plant height-control & $54.58^{\mathrm{b}} \pm 2.24$ & $69.33^{\mathrm{a}} \pm 2.84$ & $70.42^{\mathrm{a}} \pm 1.71$ & 16.69 & $<0.001$ \\
Plant weigth-control & $11.57^{\mathrm{b}} \pm 0.62$ & $15.96^{\mathrm{a}} \pm 0.38$ & $17.77^{\mathrm{a}} \pm 0.45$ & 40.86 & $<0.001$ \\
\hline
\end{tabular}


Table 7. Mean annual aboveground forage production (dry matter, $\mathrm{t} \mathrm{ha}^{-1}$ ) and above-ground forage composition (carbon and nitrogen concentrations, $\mathrm{mg} \mathrm{g}^{-1}$ ) by experimental grassland ( $\mathrm{n}$ $=4) \pm$ standard errors. Grassland with medium percentage $(50 \%)$ of grassland in the rotation (3G) and grassland with high percentage $(75 \%)$ of grassland in the rotation (6G). Similar letters denote no significant differences among treatments (Tukey HSD test) at $\mathrm{P}<0.05$ level. $\chi^{2}$-values and associated $P$-values are indicated.

\begin{tabular}{|c|c|c|c|c|c|c|}
\hline & \multicolumn{4}{|c|}{ Treatments } & \multicolumn{2}{|c|}{ Blocks } \\
\hline & $3 \mathrm{G}$ & $6 \mathrm{G}$ & $\chi^{2}$ & $P$ & $\chi^{2}$ & $P$ \\
\hline Forage production & $3.53^{\mathrm{a}} \pm 0.48$ & $3.15^{\mathrm{a}} \pm 0.34$ & 1.71 & 0.282 & 14.18 & 0.028 \\
\hline Carbon & $439.9^{a} \pm 0.1$ & $442.2^{\mathrm{a}} \pm 0.1$ & 3.15 & 0.174 & 1.13 & 0.461 \\
\hline Nitrogen & $1.91^{\mathrm{a}} \pm 0.03$ & $2.00^{\mathrm{a}} \pm 0.06$ & 3.66 & 0.152 & 6.32 & 0.082 \\
\hline
\end{tabular}




\section{FIGURE}

Figure 1. Non-Metric Multidimensional Scaling ordinations showing differences, based on Bray-Curtis dissimilarity among bacterial (a), fungal (b), arbuscular mycorrhizal fungal (AMF) (c), springtail (d), enchytraeid (e) and earthworm (f) communities (i.e the composition of OTUs or species) in crop rotation experimental treatments. Individual points represent samples and the ellipses represent the bidirectional $95 \%$ confidence interval of treatments. Significant dissimilarities between treatments were assessed by PERMANOVA. Pseudo Fvalues and associated $P$-values are indicated. Crop rotation experimental treatments: annual crops only (AC), grassland with a medium percentage $(50 \%)$ of grassland duration in the crop rotation $(3 \mathrm{G})$ and grassland with a high percentage $(75 \%)$ of grassland duration in the rotation $(6 G)$.
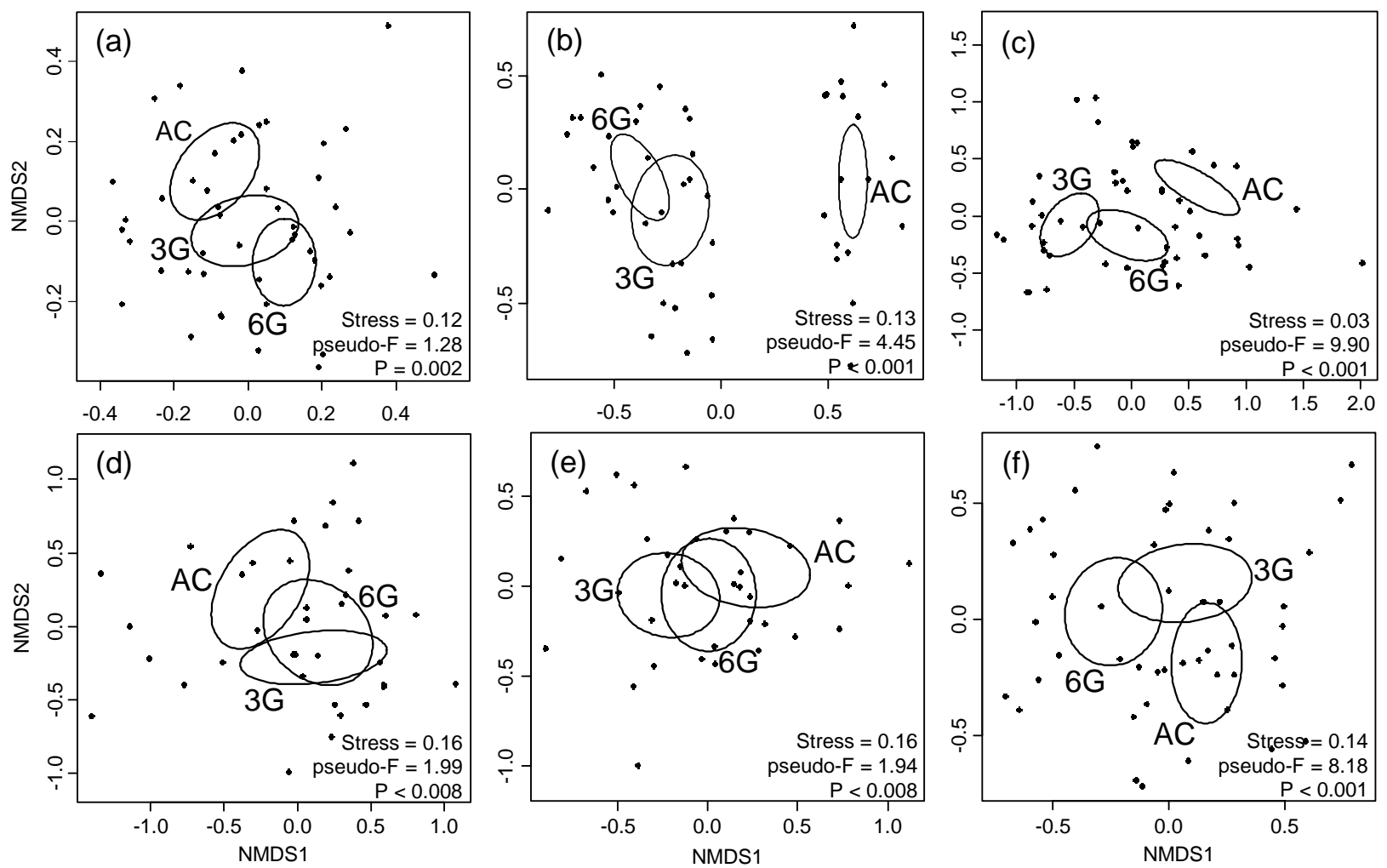


\section{CRediT author statement}

Kevin Hoeffner: Conceptualization, Formal analysis, Investigation, Writing - Original Draft, Writing - Review \& Editing, Visualization. Anneke Beylich: Methodology, Validation, Resources, Writing - Original Draft, Writing - Review \& Editing. Abad Chabbi: Resources, Writing - Original Draft, Writing - Review \& Editing. Daniel Cluzeau: Methodology, Validation, Resources, Supervision. Dumitrita Dascalu: Validation, Resources. Ulfert Graefe: Methodology, Validation, Resources. Gema Guzmán: Methodology, Validation, Resources. Vincent Hallaire: Methodology, Resources. Jörg Hanisch: Methodology, Validation, Resources. Blanca B. Landa: Methodology, Validation, Resources. Deborah Linsler: Methodology, Validation, Resources, Supervision. Safya Menasseri: Methodology, Validation, Resources. Maarja Öpik: Methodology, Validation, Resources, Writing - Original Draft, Writing - Review \& Editing. Martin Potthoff: Conceptualization, Writing - Original Draft, Supervision, Project administration, Funding acquisition. Mignon Sandor: Methodology, Validation, Resources, Writing - Original Draft. Stefan Scheu: Methodology, Validation, Ressources, Writing - Original Draft, Writing - Review \& Editing. Rüdiger M. Schmelz: Methodology, Validation, Resources, Writing - Original Draft. Ilka Engell: Methodology, Validation, Resources, Writing - Original Draft. Stefan Schrader: Methodology, Writing - Original Draft, Writing - Review \& Editing. Tanel Vahter: Methodology, Validation, Resources, Writing - Original Draft. Martin Banse: Supervision, Project administration. Annegret Nicolaï: Writing - Original Draft, Writing - Review \& Editing. Elke Plaas: Supervision, Writing - Original Draft. Tania Runge: Methodology, Writing - Original Draft. Tomas Roslin: Formal analysis, Writing - Original Draft. MarieLaure Decau: Validation, Resources. Siim-Kaarel Sepp: Methodology, Validation, Resources.

Luis F. Arias-Giraldo: Validation, Resources. Sylvain Busnot: Methodology, Validation, Resources. Marc Roucaute: Methodology, Validation, Resources. Sylvain Busnot: 
Methodology, Validation, Resources. Guénola Pérès: Conceptualization, Methodology, Writing - Original Draft, Writing - Review \& Editing, Supervision, Project administration, Funding acquisition 


\section{Declaration of interests}

$\bigotimes$ The authors declare that they have no known competing financial interests or personal relationships that could have appeared to influence the work reported in this paper.

$\square$ The authors declare the following financial interests/personal relationships which may be considered as potential competing interests: 
Graphical abstract

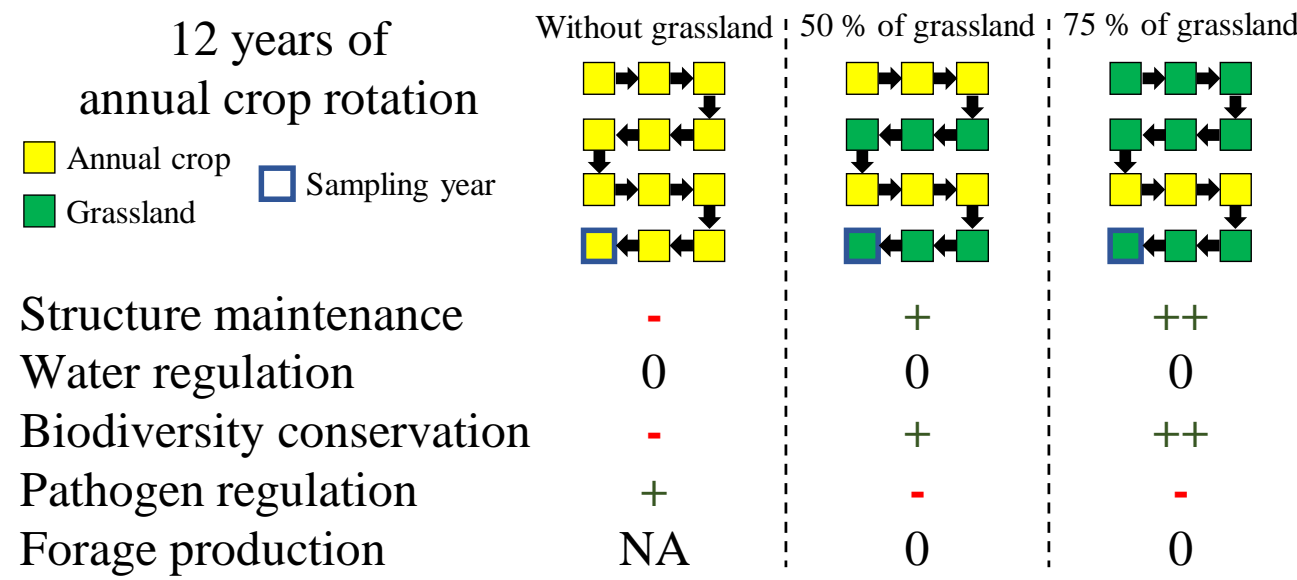

NA: not applicable, $\quad$ : no effect, -: service decreased, +/++: service improved 


\section{Highlights}

- Five ecosystem services were studied in crop rotations with or without grasslands

- Grassland introduction improves soil structure maintenance and biodiversity conservation

- Grassland introduction decreases pathogen regulation

- Grassland legacy effect improves soil structure maintenance and biodiversity conservation

- There is no legacy effect on water and pathogen regulation, nor on forage production 